SHANG-CHIN LAI

\title{
REDUCING ORGAN TRAFFICKING: NEW ZEALAND'S INTERNATIONAL AND DOMESTIC RESPONSIBILITIES
}

\author{
LLM RESEARCH PAPER \\ LAWS 513: LAW AND MEDICINE
}

FACULTY OF LAW

TE WHARE WÁNANGa O TE ÚPOKO O TE IKA A MĀUI

2013 


\section{Abstract}

Organ trafficking is a transnational issue that calls for a response from the international medical community. Despite consistent condemnation, organ trafficking persists due to the worldwide shortage of organs for transplantation. This paper discusses the human rights abuses perpetuated by organ trafficking and suggests some approaches to reducing organ trafficking and transplant tourism. The paper concludes that combating organ trafficking requires a cohesive response from the international community of states, comprising of mutually reinforcing legal reform at international and domestic levels. In particular, states should seek to lighten the burden on the worldwide shortage of organs by increasing local supply. This paper considers presumed consent to be the most effective system of organ procurement. As such the paper suggests a framework for implementing presumed consent in New Zealand, in order to increase organ donation rates.

\section{Word count}

The text of this paper (excluding abstract, table of contents, footnotes, appendices and bibliography) comprises approximately 15,616 words.

\section{Keywords}

Organ trafficking, transplant tourism, organ donation, presumed consent, Human Tissue Act 2008. 


\section{Introduction}

International organ trafficking poses an increasingly acute concern for the international medical community. The issue is rooted in the worldwide shortage of organs for transplantation. The early 1980s saw the development of ciclosporin, an immunosuppressant drug used to prevent organ rejection after transplantation. Since then, organ transplantation has become a common, life-saving procedure. ${ }^{1}$ However, the full life-saving potential of organ transplantation cannot be realised, as the worldwide demand for organ transplants exceeds the supply of organs. ${ }^{2}$ The majority of domestic organ transplantation systems rely on altruistic donations from living donors, and those who consent to have their organs donated upon death. These systems do not produce enough organs to match demand. There is a particular shortage of kidney donations, the most common form of living organ donation. ${ }^{3}$

As is inevitable where demand exceeds supply, the shortage of organ donors has led to the development of a thriving international black market in organs. The international traffic in organs is a continuing problem that requires a response from the international medical community collectively, as well as individual states. While precise figures are difficult to determine due to the nature of the trade, it was estimated at the Second Global Consultation on Human Transplantation of the World Health Organisation (WHO) in March 2007 that organ trafficking accounts for $5-10$ per cent of the kidney transplants performed annually throughout the world. ${ }^{4}$ The failure to internationally regulate the black market organ trade can be traced to a failure in both international cooperation and more alarmingly, to individual states' unwillingness to enact domestic legislation to a) reflect and uphold their international obligations vis-à-vis organ trafficking and b) to address the root problem of organ trafficking, being the shortage of donated organs for transplant. It appears that many states turn a blind eye to the problem because of the health benefits for the recipients of organs acquired through trafficking.

1 David J Rothman and Sheila M Rothman Trust is Not Enough: Bringing Human Rights to Medicine (The New York Review of Books, New York, 2006) at 5.

2 At 3.

3 A Rithalia and others "A systematic review of presumed consent systems for deceased organ donation" (2009) 13 Health Technology Assessment 1at 1.

4 D A Budiani-Saberi and F L Delmonico "Organ Trafficking and Transplant Tourism: A Commentary on the Global Realities" (2008) 8 American Journal of Transplantation 925 at 925. 
This paper argues that organ trafficking is an issue of international scope that requires mutually reinforcing responses from the international medical community and domestic legal systems. The response must be twofold: first, it must seek to stop the existing organ traffic through criminalisation of organ trading and enforcement and secondly, it must address the root cause of organ trafficking - the worldwide shortage of organs for transplantations. The worldwide shortage of organs is best addressed through increasing local supply of organs to meet domestic transplantation needs. International solutions will be unsuccessful unless accompanied by domestic legislation, especially given the wide differences in healthcare across states and the unique cultural, religious and societal considerations of each state in formulating health policy.

Part II of this paper provides a brief overview of organ trafficking and its effects. Part III discusses theoretical underpinnings of organ procurement, which has traditionally been rooted in altruism. Part IV discusses the components required for a cohesive response to organ trafficking, which encompasses both international and domestic measures. This paper argues that in practical terms, introducing more effective organ procurement systems into domestic legislation will deliver more immediate outcomes for increasing the organ supply than international solutions. As such, Part V will present and analyse the commonly proposed approaches to increasing domestic organ supply. These proposed approaches include: conscription, mandated choice, soft presumed consent, hard presumed consent, and non-financial incentives. This paper's preferred approach is hard presumed consent. Part VI considers practical aspects in implementing presumed consent. Change begins at home; thus Part VII outlines a framework for presumed consent in New Zealand. Māori perspectives on organ donation must inform the discussion on a proposed presumed consent system in New Zealand.

Focus will be had on New Zealand. First, New Zealand is implicated in the worldwide shortage of organs. According to Organ Donation New Zealand, in 2012 there were a total of 174 transplant operations from live and deceased donors. ${ }^{5}$ At 8.6 per million people for deceased donors and 12.9 per million for living donors, New Zealand's

5 Organ Donation New Zealand "Statistics" <www.donor.co.nz>. 
current organ donation rates are among the lowest in the developed world. ${ }^{6}$ Secondly, New Zealand provides an example for how other states might also implement presumed consent in order to increase domestic supply. Each state that effectively addresses its own organ shortage lessens the burden of the worldwide shortage, thereby adding to the overarching mutually enforcing domestic and international response to organ trafficking.

This paper concludes that, given the reality of organ trafficking, the international medical community should simultaneously consider ways of ameliorating the currently ineffective international regulation of organ trafficking whilst promoting domestic presumed consent legislation for organ donation. New Zealand must actively consider moving to a presumed consent system for organ donation.

\section{Organ Trafficking Background}

This Part briefly outlines how organ trafficking works and its effects. This paper proceeds on the basis that organ trafficking is an existing and ongoing concern for the international medical community. It focuses on international and domestic solutions for reducing organ trafficking, rather than particulars such as trading routes, donor demographics or statistics.

\section{A Definitions}

In 2009 the WHO published a glossary of terms and definitions, noting the need for globally uniform terminology to clarify communication in the area of donation and transplantation. ${ }^{7}$ This paper uses the WHO definitions as the internationally accepted definitions, despite the fact that they are not binding legal definitions at international law. The WHO is the body responsible for international health matters for member states of the United Nations, of which New Zealand and the case studies discussed in this paper are member states. Thus the definitions are useful reference points. Many of the definitions refer specifically to the domestic laws of member states. ${ }^{8}$ As such, the glossary serves as a guideline for lawmakers in individual states, while the law is recognised as the appropriate regulatory means for domestic organ transplantation.

6 Organ Donation New Zealand "International Donor Rates" < www.donor.co.nz>.

7 World Health Organisation "Global Glossary of Terms and Definitions on Donation and Transplantation" (Geneva, November 2009) at 3. The key definitions are given in the main text. For further useful definitions see Appendix 1.

8 See for example the definitions of 'exporting', 'importing' and 'consent'. 
According to the WHO, organ trafficking is: ${ }^{9}$

[t]he recruitment, transport, transfer, harboring or receipt of living or deceased persons or their cells, tissues or organs, by means of the threat or use of force or other forms of coercion, of abduction, of fraud, of deception, of the abuse of power or of a position of vulnerability, or of the giving to, or the receiving by, a third party of payments or benefits to achieve the transfer of control over the potential donor, for the purpose of exploitation by the removal of cells, tissues and organs for transplantation.

Transplant tourism is: ${ }^{10}$

[t]ravel for transplantation when it involves organ trafficking and/or transplant commercialism or if the resources (organs, professionals and transplant centers) devoted to providing transplant to patients from outside a country undermine the country's ability to provide transplant services for its own population.

Transplant commercialism is "a policy or practice in which cells, tissues or organs are treated as a commodity, including by being brought or sold or used for material gain."11

For ease of reference, 'donors' will be used throughout this paper to refer to those who give their organs for transplantation, whether altruistically or as a result of organ trafficking, although in the strict sense organ trafficked persons cannot truly be considered 'donors'. ${ }^{12}$

\section{B How Organ Trafficking Works}

Organ trafficking is a transnational operation, involving any number of people from different states. More individuals are involved beyond the 'donor' and the organ recipient. There are typically organ brokers, who source the organ, transport and deliver the organ, organise travel for 'donors' and recipients, and collect the money. ${ }^{13}$ There are the medical professionals who perform the organ transplantations. All of these individuals may come from the same state, or each from a different state. The

9 World Health Organisation, above n 7, at 14.

10 At 14.

11 At 14

12 See Appendix 1 for the WHO definition of 'donor'.

13 I Glenn Cohen "Transplant Tourism: the Ethics and Regulation of International Markets for Organs" (2013) 41 J L Med \& Ethics 269 at 273. 
numerous combinations of persons and states implicated in the organ trafficking chain inevitably give rise to difficulties in international regulation. It becomes difficult to determine a) precisely where culpability should lie and b) which states are responsible for which part of the organ trafficking chain.

Trafficking in organs occurs in two broad categories. First, there are cases where traffickers coerce, threaten or deceive the 'donor' into giving up an organ. Secondly, there are cases where 'donors' agree to sell an organ and are cheated because they are not paid for the organ or are paid less than the promised price. ${ }^{14}$ Forms of organ trafficking and transplant tourism, include (but are not limited to): ${ }^{15}$

- A recipient travelling from State $\mathrm{A}$ to State $\mathrm{B}$, where the donor and the transplant centre are located;

- A donor travelling from State A to State B, where the recipient and transplant centre are located;

- A donor and a recipient travelling from State A to State B where the transplant centre is located;

- A donor from State A and a recipient from State B travelling to State C where the transplant centre is located.

High-exporting organ states include India, Pakistan, the Philippines, Turkey and Colombia. ${ }^{16}$ High-importing states (referring to the states of origin of those who purchase organs for transplantation) include Israel, Canada, Japan, Australia, the United States, Saudi Arabia and Oman. ${ }^{17}$

\section{Human Rights Issues}

There are obvious human rights issues associated with organ trafficking. The international black market in organs resulting from the worldwide shortage gives rise to many human rights abuses. ${ }^{18}$ The WHO definition for organ trafficking includes

14 Sheri R Glaser "Formula to Stop the Illegal Organ Trade: Presumed Consent Laws and Mandatory Reporting Requirements for Doctors" (2005) 12 Hum Rts Brief 20 at 20.

15 Budiani-Saberi and Delmonico, above n 4, at 926.

16 Yosuke Shimazono "The state of the international organ trade: a provisional picture based on integration of available information" (2007) 85 Bulletin of the World Health Organisation 955 at 957.

17 At 957.

18 Sarah Elizabeth Statz "Finding the Winning Combination: How Blending Organ Procurement Systems Used Internationally Can Reduce the Organ Shortage" (2006) 39 Vand J Transnatl L 1677 at 1679 . 
terms such as use of force, coercion, abduction, fraud, deception, abuse of power and exploitation. ${ }^{19}$ An illegal organ procurement method that encompasses one or more of the above cannot be anything but a breach of human rights. Organ trafficking violates the right to human dignity, the right to life, the right to self-determination, the right to liberty, the right to security in prison and the right to freedom from cruel or inhumane treatment.

The Preamble to the Universal Declaration of Human Rights (UDHR) emphasises that the "inherent dignity... of the human family is the foundation of freedom, justice and peace in the world". ${ }^{20}$ Human dignity is further affirmed in art $1 .{ }^{21}$ The International Covenant on Civil and Political Rights (ICCPR) and the International Covenant on Economic, Social and Cultural Rights (ICESCR) also note, using identical wording, that "the rights [contained within] derive from the inherent dignity of the human person"22 Human dignity is stripped where a person is forced into a position in which they are vulnerable to organ trafficking.

Both the ICCPR and ICESCR guarantee the right to self-determination. ${ }^{23}$ Organ trafficking removes the right to self-determination, by removing the trafficked person's ability to make a free and informed choice about their healthcare and whether or not to give up an organ.

Article 6 of the ICCPR guarantees the right to life. ${ }^{24}$ Article 7 protects against "torture...cruel, inhumane or degrading treatment or punishment" as well as subjection "without free consent to medical or scientific experimentation". ${ }^{25}$ Organ trafficking may breach both of these articles. Exploitation of prisoners for organs breaches arts 9 and $10 .{ }^{26}$ Finally, the ICESCR recognises "the right of everyone to the

World Health Organisation, above $\mathrm{n}$ 7, at 14.

Universal Declaration of Human Rights (ratified 10 December 1948), Preamble.

Article 1.

International Covenant on Civil and Political Rights 999 UNTS 171 (opened for signature 16 December 1966, entered into force 23 March 1976), Preamble; International Covenant on Economic, Social and Cultural Rights 993 UNTS 3 (opened for signature 16 December 1966, entered into force 3 January 1976), Preamble.

23 Article 1 of both Covenants.

24 Article 6.

25 Article 7.

26 Articles 9 and 10. Respectively the right to liberty and security in prison and the right of persons deprived of their liberty to be treated with humanity and respect for the inherent dignity of the human person. 
enjoyment of the highest attainable standard of physical and mental health"27, which is implicated when victims of organ trafficking receive inadequate medical care during and following organ removal. The commercial transaction is the central aspect of organ trafficking; the organ becomes a commodity and financial considerations often become the priority over the health and well-being of both the 'donors' and recipients. $^{28}$

In practice it is difficult to enforce the broadly framed rights contained within the international human rights instruments. Claims under these international instruments must be brought against states; it is unlikely that a victim of organ trafficking would have the resources to do so. Further, the breaches are too broad to attribute to the actions of any one state. For example, while being coerced or deceived into donating an organ may breach art 7, it is difficult to frame being forced to sell an organ due to poverty in relation to the conduct of a state. Many states do not stringently enforce laws against organ sales. In China, organ trafficking has developed as a by-product of China's use of the death penalty. Although China is a signatory to the ICCPR, it is an open secret that officials remove organs from executed prisoners to sell for use in transplant surgeries, which breaches arts 9 and 10. Although China's official stance is to ban the buying or selling of human organs and tissues, the practice nonetheless continues. $^{29}$

\section{Informed Consent and Individual Autonomy}

In addition to international human rights law, organ trafficking also infringes upon two key principles of medical ethics: individual autonomy and informed consent. The right to human dignity gives rise to the right to individual autonomy, which in turn gives rise to the right to bodily integrity. ${ }^{30}$ Individual autonomy is given effect through the doctrine of informed consent. The principles of individual autonomy and informed consent form the basis of medical law and ethics in many Western states, including New Zealand. ${ }^{31}$ The New Zealand Code of Health and Disability Services

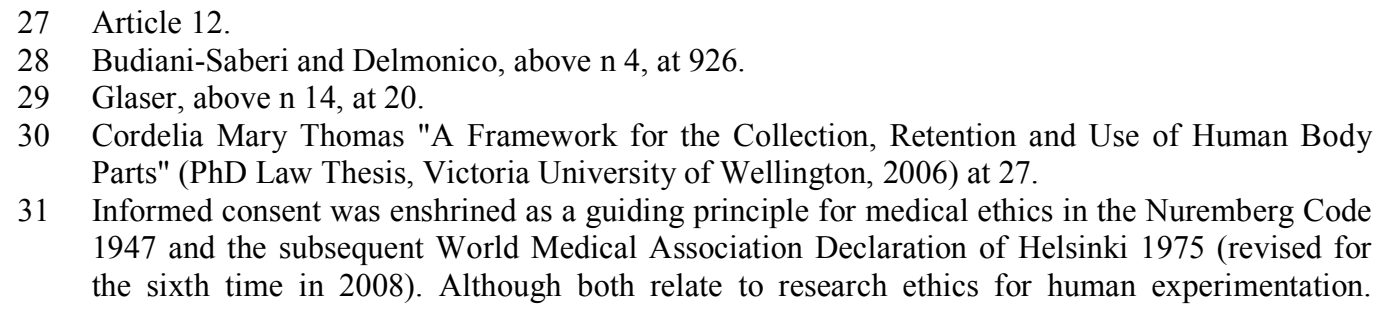
1947 and the subsequent World Medical Association Declaration of Helsinki 1975 (revised for the sixth time in 2008). Although both relate to research ethics for human experimentation. 
Consumer Rights 1996 (the Code), which applies to all health care and disability services in New Zealand, illustrates the importance of informed consent and individual autonomy.

Organ procurement necessitates involvement from medical professionals. Thus, organ trafficking victims are arguably health service consumers, and are entitled to the rights of any other patient. Although individual states have different standards of patients' rights and codes of ethics, the New Zealand Code will be used as an illustration of the potential breaches of patients' rights resulting from organ trafficking.

The Code is known as the patients' bill of rights. It sets out rights, which are legally enforceable under the Health and Disability Commissioner Act 1994. ${ }^{32}$ Organ trafficking breaches the right to be treated with respect, the right to freedom from discrimination, coercion, harassment and exploitation, and the right to dignity and independence. ${ }^{33}$ The most comprehensively detailed rights are the right to be fully informed, ${ }^{34}$ and the right to make an informed choice and give informed consent. ${ }^{35}$ Under Rights 6(1) and (2), the consumer has a right to receive the information that a reasonable consumer, in that consumer's circumstances, would expect to receive, in order to make an informed choice. An organ trafficking victim is unlikely to receive such information.

Informed consent is the cornerstone of the Code. Under Right 7(1) services may only be provided if that consumer makes an informed choice and gives informed consent. Further, under Right 7(7) every consumer may refuse or withdraw consent to services and Right 7(10)(a) notes that no body part may be used without the informed consent of the consumer. The strength of the Code lies in its recognition that informed consent is not a one-off action to authorise a medical intervention, but a process with a number of components, including competence, voluntariness, effective communication, provision of sufficient information and the giving of consent. ${ }^{36}$ The

informed consent has since become an accepted principle of medical ethics applicable to all medical services.

32 Joanna Manning (ed) The Cartwright Paper: Essays on the Cervical Cancer Inquiry $1987-88$ (Bridget Williams Books, Wellington, 2009) at 151.

33 Code of Health and Disability Services Consumers' Rights 1996, right 1, 2, and 3.

34 Right 6.

35 Right 7.

36 Manning, above n 32, at 159. 
exploitative nature of organ trafficking does not give effect to any of these elements of informed consent.

The Code is consistent with the WHO glossary definition of consent. ${ }^{37}$ Ethically justifiable organ donation requires the voluntary decision of consent from a competent donor on the basis of adequate information. Informed consent must underpin both deceased and living organ donation. Organ trafficking does not reflect this fundamental principle of medical ethics. For this reason, and the human rights abuses discussed above, organ trafficking is an unacceptable form of organ procurement.

\section{Theoretical Underpinnings}

\section{A Altruism in Medicine}

Organ trafficking stems from a worldwide organ shortage, which is the result of a scarcity in both deceased and living organ donors. To date, an altruistic approach has driven organ procurement. This Part outlines the altruistic approach and discusses why altruism should remain the basis for organ procurement and should form the basis of any proposed solutions to the worldwide organ shortage.

The seminal work on altruism in social policy is Richard Titmuss' 1970 book The Gift Relationship. The work examined whether medical care, in its many component parts, is a consumption good indistinguishable from other goods and services in a private economic market, through a comprehensive survey of blood donors in England and Wales, and the United States. ${ }^{38}$ The key concern of the study was the national and international consequences of treating human blood as a commercial commodity, and where the lines should be drawn if blood were legitimised as a consumption good..$^{39}$

Titmuss concluded that treating human blood as a saleable good would have dangerous ramifications for healthcare policy, and social policy in general. All policy would then essentially become economic policy. ${ }^{40}$ Titmuss noted that human welfare is an ethical concept and there is no such thing as economic welfare. Thus a society that recognises the social good of social healthcare policy cannot at the same time

37 See Appendix 1.

38 Richard M Titmuss The Gift Relationship: From Human Blood to Social Policy (George Allen \& Unwin, London, 1970) at 12.

39 At 12

40 At 12. 
accept monetary exchange for blood donation. Monetary value cannot be attached to the spirit of altruism within a society. ${ }^{41}$ Commercialisation of blood and donor relationships represses the expression of altruism, erodes a sense of community, lowers scientific standards, limits both personal and professional freedoms, sanctions the making of profits in hospitals, subjects critical areas of medicine to the laws of the marketplace, places immense social costs on those least able to bear them, increases the danger of unethical behaviour in various sectors of medical science and practice and results in situations where proportionately more and more blood is supplied by the poor. ${ }^{42}$

Titmuss' work affirms the proposition that trade in human body parts is not ethically desirable and that altruism should underpin organ procurement. Shifting away from an altruistic system would mean a loss of the social benefits of the donation process most importantly the valuable social interaction and community building that lies in enhancing or saving another's life. ${ }^{43}$ Organ transplantation is arguably the most intensely social of all medical practices, as it relies upon a unique trust between society and medical professionals and is dependent on the willingness of ordinary people to share their organs with a loved one or even a stranger. ${ }^{44}$ Moving away from an altruistic approach in organ procurement, with its strong tradition of social interaction, would require a fundamental shift in conception of medical ethics and the language of social justice. ${ }^{45}$

\section{B Marketisation?}

Some scholars call for legalisation of the market in both living and deceased organs, suggesting that a market-based approach to organ procurement would more effectively combat organ trafficking by closing the gap between supply and demand. ${ }^{46}$

41 Titmuss, above $\mathrm{n} 38$, at 198

42 At 224.

43 Christian Williams "Combatting the Problems of Human Rights Abuses and Inadequate Organ Supply Through Presumed Donative Consent" (1994) 26 Case W Res J Int'l L 315 at 335.

44 F L Delmonico and Nancy Scheper-Hughes "Why We Should Not Pay For Human Organs" (2003) 38 Zygon 689 at 689.

45 At 696.

46 See for example Lloyd R Cohen "Increasing the Supply of Transplant Organs: The Virtues of a Futures Market" (1990) 58 Geo Wash L Rev 1; Michael P Jaycox "Coercion, Autonomy, and the Preferential Option for the Poor in the Ethics of Organ Transplantation" (2012) 12 Developing World Bioethics 135 at 136; Richard Michael Boyce "Organ Transplantation Crisis: Should the Deficit Be Eliminated Through Inter Vivos Sales?" (1984) 17 Akron L Rev 283; Michael B Gill and Robert M Sade "Paying for Kidneys: The Case against Prohibition" (2002) 12 Kennedy 
Proponents of marketisation found their arguments in the right to individual autonomy; an individual should be allowed to do whatever they wish with their organs. ${ }^{47}$

The significant body of literature arguing for various forms of a legal organ market is not canvassed. Moreover, the corollary question of property in body parts, essential to regulating a legal market is not discussed. First, this paper considers that organ procurement is properly driven by altruism. Secondly, even if a legal market in organs could be justified on a philosophical level, practical implementation of a legal organ market is unfeasible, particularly in New Zealand. The focus of this paper is on practical suggestions for reform of organ procurement law in New Zealand, which will lighten the burden on the international shortage of organs by removing any incentive for New Zealanders to participate in the organ trafficking chain.

In his recent book Michael Sandel echoes Titmuss' conclusions as to the undesirability of commodifying healthcare. ${ }^{48}$ Sandel applies two arguments against marketisation of moral goods: fairness and corruption. The fairness objection considers the inequality that market choices may reflect; the corruption objection considers the attitudes and norms that market relations may damage or dissolve. ${ }^{49}$ Applied to organs, the fairness argument is concerned with the exploitation of the poor in an organ market, pointing to the injustice that can arise when people buy and sell things under conditions of inequality or dire economic necessity. The choice to sell an organ may not be truly voluntary. The corruption argument is concerned with the idea that such markets promote a degrading, objectifying view of the human person. ${ }^{50}$ The argument for corruption cannot be met by establishing fair bargaining conditions; it applies under conditions of equality and inequality alike. ${ }^{51}$

The fairness objection hinges upon the potential for exploitation, suggesting that a market in organs is not in itself morally wrong, only so far as it entrenches

Institute Ethics J 17; Arthur J Matas "The Case for Living Kidney Sales: Rationale, Objections and Concerns" (2004) 4 American Journal of Transplantation 2007.

47 Sunny Woan "Buy Me a Pound of Flesh: China's Sale of Death Row Organs on the Black Market and What Americans Can Learn From It" (2007) 47 Santa Clara L Rev 413 at 438; Delmonico and Scheper Hughes, above $\mathrm{n} 44$, at 693.

48 Michael Sandel What Money Can't Buy: The Moral Limits of Markets (Penguin Group, London, 2013).

49 At 110.

50 At 110.

51 At 111. 
inequality. ${ }^{52}$ In practice however, it is unlikely that legalising the organ market and attempting to regulate it would help alleviate inequality between organ sellers living in states with poor enforcement mechanisms, and wealthy buyers. It may also entrench inequalities between buyers, some of whom may not be able to afford a lifesaving organ. Society recognises that healthcare should not be something that the rich may have but not the poor. The very fact that healthcare is government funded in New Zealand reflects the fact that our society frowns upon the questionable morality of allowing a basic need to be determined by financial status. Governments in developing states that are unable, or unwilling to eliminate the black market in organs, are unlikely to have the resources to effectively regulate a legal market. ${ }^{53}$ Thus any market in organs continues to be morally objectionable. Moreover, there is danger in offering financial incentives to people who would be willing to engage in an activity for altruistic reasons. When people are engaged in an activity they consider morally worthwhile, offering them money may weaken their motivation by "crowding out" their intrinsic moral conviction, defeating the foundations of social health care policy. ${ }^{54}$

On a practical level, both the WHO and World Medical Association (WMA) strongly oppose financial incentives for organ donation, whether living or deceased. ${ }^{55}$ In 2010 , the decision-making body of the WHO, the World Health Assembly (WHA) urged member States, including New Zealand, to: ${ }^{56}$

...promote the development of systems for the altruistic voluntary non-remunerated donation... of organs.

...[and] oppose the seeking of financial gain or comparable advantage in transactions involving human body parts, organ trafficking and transplant tourism, including by encouraging healthcare professionals to notify relevant authorities when they become aware of such practices in accordance with national capacities and legislation.

52 At 111.

53 Jaycox, above n 46, at 145.

54 Sandel, above n 48, at 122.

55 See World Health Organisation "WHO Guiding Principles on Human Cell, Tissue and Organ Transplantation" (2010); World Medical Association "Statement on Human Organ, Tissue Donation and Transplantation" (52nd General Assembly, Edinburgh, October 2000).

56 World Health Organisation Human organ and tissue transplantation WHA63.22 (2010), art 2(3). 
Moving to a legal market would require a significant and controversial shift in healthcare policy likely to be contrary to public opinion. ${ }^{57}$ In New Zealand, trading in human tissue for financial gain is prohibited generally, subject to exemptions, under $\mathrm{s}$ 56 of the Human Tissue Act 2008. ${ }^{58}$ Further, there are currently inadequate regulations and enforcement against organ trafficking, on both international and national levels, offering little confidence that a market in organs could be effectively regulated. Therefore, any proposals for increasing the worldwide organ shortage must remain rooted in altruism.

\section{Reducing Organ Trafficking}

To date, neither the international community as a whole, nor the individual states within it have responded adequately to the problem of organ trafficking. Attempts to regulate the crime of organ trafficking are characterised by gaps in legal provisions, weak enforcement and few prosecutions. ${ }^{59}$ Exploitation of prisoners and poor citizens of developing countries calls for a cohesive international response ${ }^{60}$ Laws are needed that encourage organ donation through legitimate and ethical channels while reducing human rights abuses. The existence of the international black market and widespread transplant tourism shows that the solution to the organ procurement problem must be dealt with on both an international level and a domestic level. ${ }^{61}$ Cohen suggests a fourfold approach to reducing organ trafficking: ${ }^{62}$

1. Destination country enforcement;

2. International documents;

3. Home country measures including extraterritorial criminalisation;

4. Improving allocation and supply of organs locally.

This approach recognises that organ trafficking is a transnational crime, while acknowledging that the shortage of organs must also be addressed on a domestic level, due to the vast differences in resources between organ importing and exporting

57 Erica Teagarden "Human Trafficking: Legal Issues in Presumed Consent Laws" (2005) 30 NCJ Intl \& Com Reg 685 at 698.

58 See Appendix 3 for the full text of this provision. Section 56 will be discussed further in Part IVC.

59 Glaser, above n 14, at 20.

60 Statz, above n 18 , at 1682.

61 At 1680.

62 I Glenn Cohen, above n 13, at 279. 
states and the differing capacity of governments to implement health care policy. The following Parts discuss each of the components of Cohen's framework for reducing organ trafficking, with reference to New Zealand. The New Zealand experience illustrates how the framework might be applied in other states, which form the international medical community. Particular emphasis is placed on improving allocation and supply of organs locally.

\section{A Destination Country Enforcement}

The most straightforward solution is for individual states to ban illegal organ sales and prosecute brokers and medical tourists who purchase organs alike. In theory every state but Iran currently criminalises organ sale. However, as seen in Part II, organ trafficking and transplant tourism persists in spite of official legal sanctions. First, states such as China turn a blind eye because enforcement is a priority of neither national law nor international law, and doing so allows a state to ameliorate its local organ shortage without using state resources. Secondly, the transnational and multimodal nature of organ trafficking means it is one of the most difficult crimes to detect and control within any single jurisdiction. ${ }^{63}$ Universal response to organ trafficking is condemnation, but awareness and expertise on how to detect and enforce the crime is practically nonexistent. Thus while domestic criminal prosecutions in destination states should be encouraged, they are unlikely to be effective on their own in ending organ trafficking. ${ }^{64}$ The growth of the illegal international organ trade is properly considered an international medical law issue. ${ }^{65}$

\section{B International Law}

International law on organ trafficking faces three problems. First, little by way of binding international law specifically addresses the issue. Secondly, there is no international enforcement mechanism for the little international law that does exist. Thirdly, States parties to the existing international law are unwilling or unable to uphold their international obligations to that effect.

\section{Existing International Law}

63 Leslie P Francis and John G Francis "Stateless Crimes, Legitimacy, and International Criminal Law: The Case of Organ Trafficking" (2010) 4 Crim L and Philos 283 at 289.

64 I Glenn Cohen, above n 13, at 279.

65 Yosuke Shimazono, above n 16, at 959. 
The Protocol to Prevent, Suppress, and Punish Trafficking in Persons, Especially Women and Children (the Protocol), which supplements the United Nations Convention against Transnational Organised Crime (the Convention), requires States parties to criminalise and to establish policies to prevent trafficking in persons. ${ }^{66}$ "Organ removal" and sale is included under the definition of human trafficking, as an exploitative purpose of human trafficking. ${ }^{67}$ The purposes of the Protocol include preventing and combating trafficking in persons ${ }^{68}$ and promoting cooperation among States parties in order to meet those objectives. ${ }^{69}$ The Protocol is concerned with human trafficking in general; organ trafficking is one of the negative results of human trafficking, but not the central focus. New Zealand is party to both the Convention and the Protocol. ${ }^{70}$

Similarly, the Council of Europe Convention on Action Against Trafficking in Human Beings (CEC) includes "removal of organs" in the definition of "trafficking in human beings...for the purpose of exploitation"71 and requires parties to the Convention to "take measures to establish or strengthen national co-ordination between the various bodies responsible for preventing and combating trafficking in human beings". ${ }^{72}$ The Additional Protocol to the Convention on Human Rights and Biomedicine concerning Transplantation of Organs and Tissues of Human Origin (Additional Protocol) also prohibits organ trafficking. ${ }^{73}$ However, neither the CEC nor the Additional Protocol impose obligations on states parties other than to cooperate and co-ordinate. Further, the CEC and the Additional Protocol is open only to European signatories.

In 2010 the WHO issued revised Guiding Principles on Human Cell, Tissue and Organ Transplantation that states "cells, tissues and organs should only be donated

66 Articles 5 and 9.

67 Article 3.

68 Article 2(a).

69 Article 2(c).

70 United Nations Treaty Collection "Status of Ratification" < treaties.un.org>. There are 177 States parties to the Convention and 156 States parties to the Protocol. New Zealand has ratified both, along with India, the Philippines, Turkey, Colombia, Israel, Canada, the US, Australia, Japan, Oman and Saudi Arabia. These states were all identified as either high importing or exporting states in Part IIB of this paper.

71 Council of Europe Convention on Action Against Trafficking in Human Beings CETS 197 (opened for signature 16 May 2005, entered into force 1 February 2008), art 4.

72 Article 5

73 Council of Europe Additional Protocol to the Convention on Human Rights and Biomedicine concerning Transplantation of Organs and Tissues of Human Origin ETS 186 (opened for signature 25 January 2005, entered into force 1 December 2009), art 22. 
freely...without monetary payment." ${ }^{17}$ The WMA notes "payment for organs and tissues for donation and transplantation should be prohibited. A financial incentive compromises the voluntariness of the choice." ${ }^{175}$ The WHO and WMA do not have authority to enforce their guidelines. Instead, both bodies merely provide guidance to states and domestic medical associations and desperate buyers and sellers rarely follow such guidance. ${ }^{76}$

International law relating to organ trafficking is a by-product of conventions on human trafficking. Lumping the adverse effects of organ trafficking into the same category as human trafficking is dangerous, because the two crimes are overlapping, but not identical. Appending "the removal of organs" onto a provision against human trafficking is clumsy and opens a gap in the law that organ brokers may slip through. Organ trafficking is unique because the ultimate recipients of the organs are often worthy and desperate individuals, who may not realise the origin of the organ, or may not care to find out. The complex chain of organ trafficking and the range of individuals implicated in the process means that organ trafficking is a crime that deserves standalone regulation. Medical professionals are also implicated in the process and organ trafficking infringes on principles of medical ethics. The medical element of informed consent and bodily integrity separates organ trafficking from the other effects of human trafficking. Criminalising organ trafficking requires sanctions upon medical professionals who facilitate the process. It should at least be considered a distinct aspect of transnational organised crime under the Convention, given effect through a separate Protocol.

\section{Enforcement - a role for the International Criminal Court?}

There is no international enforcement regime for organised transnational crime under the Convention. The Protocol requires individual states to criminalise removal of organs as a result of human trafficking, but contains neither in-built sanctions on states for failing to criminalise, nor specifies how a state might enforce such a rule. The best solution to the problem of enforcement is to have international law directly involved, although this may be out of reach for the immediate future.

\footnotetext{
World Health Organisation, above n 55, Principle 5.

World Medical Association, above n 55.

Erica Teagarden, above n 57 at 687.
} 
As it stands, the International Criminal Court (ICC) does not have jurisdiction over any aspects of the Convention, much less organ trafficking. The jurisdiction of the Court is limited to the most serious crimes of concern to the international community as a whole: genocide, crimes against humanity, war crimes, and crimes of aggression. ${ }^{77}$ The ICC may only prosecute individuals for the listed crimes. ${ }^{78}$ Of the listed crimes, organ trafficking would most likely fall under crimes against humanity. Crimes against humanity include "other inhumane acts...intentionally causing great suffering, or serious injury to body or to mental or physical health". ${ }^{79}$ However, the acts must be committed "as part of a widespread or systematic attack directed against a civilian population." 80 Organ trafficking does not have this quality. The person who is in need of a transplant usually does not have malicious intent. Organ procurement itself, leaving aside the exploitative process, can be considered a societal good - as lives are saved. Thus organ trafficking can be distinguished from the crimes within the ICC jurisdiction. Those crimes involve states of mind such as intent to destroy a whole national, ethnical, racial or religious group. ${ }^{81}$ It cannot be said that organ brokers or buyers have the required mental state. It is difficult to equate desire for financial gain with the seriousness of intent required for ICC crimes.

In the negotiations leading to the Rome Statute there were proposals to include additional crimes under the jurisdiction of the Court including crimes of terrorism and crimes concerning illicit trafficking in drugs, which were rejected. ${ }^{82}$ The Committee of the Whole noted that drug trafficking or similar crimes were not core crimes that were undoubtedly of international concern, although they were of serious and valid national concern. ${ }^{83}$ The Committee considered that the jurisdiction of the Court should be restricted to the core crimes at the first stage, especially because drug trafficking and terrorism were already subjects of multilateral treaties. ${ }^{84}$ This

77 Rome Statute of the International Criminal Court 2187 UNTS 38544 (opened for signature 17 July 1998, entered into force 1 July 2002), art 5. Crimes of aggression will not come into force until 2017.

78 Article 25. Most often these are former heads of states or leaders of revolutions.

79 Article 7(1)(k).

80 Article 7(1).

81 Article 6.

82 United Nations Office on Drugs and Crime Travaux Préparatoires of the negotiations of the United Nations Convention against Transnational Organised Crimes and the Protocols thereto (United Nations, 2006) at [17].

83 At [32].

84 At [70] and [117]. 
reasoning may be applied to organ trafficking, which is under the Convention and the Protocol.

Lacking the force of an international judicial body has meant that international law relating to organ trafficking has met with limited implementation and limited success. In order for international law to address organ trafficking directly there must be first, a new convention or a protocol to existing Convention on transnational crime that directly addresses the question and secondly, a body for bringing claims, for enforcement and for ensuring states meet their domestic enforcement obligations, falling perhaps under the supervision of the WHO.

\section{Extraterritorial Criminalisation}

States can also deter organ trafficking and transplant tourism by adopting their own measures to govern their citizens who receive organs illegally purchased abroad, stopping them from doing so through extraterritorial legislation. ${ }^{85}$

New Zealand is party to the Convention and the Protocol. In order for the provisions of the Protocol to have effect, they must be incorporated into domestic legislation. As such, the Crimes Act 1961 criminalises human trafficking, with organ removal as its subsidiary, in accordance with art 5 of the Protocol. ${ }^{86}$ Trafficking in people by means of coercion or deception is a crime under s $98 \mathrm{D}$. According to s $98 \mathrm{D}(1):^{87}$

Every one is liable to the penalty stated in subsection (2) who-

(a) arranges the entry of a person into New Zealand or any other State by 1 or more acts of coercion against the person, 1 or more acts of deception of the person, or both; or

Under s $98 \mathrm{D}(1)(\mathrm{b})$ having a role in the concealment and harbouring of a person who has been coerced under s $98 \mathrm{D}(1)(\mathrm{a})$ in New Zealand or any other state is also a crime. ${ }^{88}$ Proceedings may be brought even if the person coerced or deceived "did not in fact enter the State concerned" or "was not in fact received, concealed, or

85 I Glenn Cohen, above n 13, at 281.

86 Protocol to Prevent, Suppress and Punish Trafficking in Persons, Especially Women and Children, supplementing the United Nations Convention against Transnational Organised Crime 2237 UNTS 319 (opened for signature 15 November 2000, entered into force 25 December 2003), art 5.

87 Crimes Act 1961, s 98D.

88 Section $98 \mathrm{D}(1)(\mathrm{b})$. The full text of the provision is set out in Appendix 3. 
harboured in the State concerned". ${ }^{89}$ Under s 98E, aggravating factors for sentencing include:

- Whether the bodily harm or death occurred during the commission of the offence ${ }^{90}$

- Whether a person in respect of whom the offence was committed was subjected to inhuman or degrading treatment as a result of the commission of the offence ${ }^{91}$

- Whether a person in respect of whom the offence was committed was subjected to exploitation (for example...the removal of organs) as a result of the commission of the offence; ${ }^{92}$

- Whether the person convicted committed the offence, or took actions that were part of it, for a material benefit. ${ }^{93}$

The Crimes Act provisions against human trafficking have extraterritorial effect. Section 7A of the Crimes Act allows for extraterritorial jurisdiction of crimes with transnational aspects. ${ }^{94}$ Sections $98 \mathrm{C}$ and $98 \mathrm{D}$ apply to persons trafficked into "New Zealand or any other state". ${ }^{95}$ Under s $98 \mathrm{~F}$, the Attorney-General's consent to prosecutions in a New Zealand court for human trafficking must be obtained. ${ }^{96}$ These provisions target brokers who traffic individuals into New Zealand or out of New Zealand or any other state for the purposes of organ procurement. However they do not address the issue of those who travel overseas to buy an organ there and have a transplant at the same time. In any case, if this sort of transplant tourism takes place in a state where the provisions against organ sales are not enforced, it is difficult to see how New Zealand law can prevent New Zealand citizens from taking advantage of another country's system, unless a specific offence is created in New Zealand.

Section 98D(1) criminalises human trafficking. However, the section focuses on the physical removal of a person from one state to another. The removal of organs is only an aggravating factor in the crime of human trafficking, rather than a crime in itself. Further, since the section targets human trafficking, it does not address situations in

89 Section $98 \mathrm{D}(3)(\mathrm{a})-(\mathrm{b})$.

90 Section $98 \mathrm{E}(1)(\mathrm{a})$.

91 Section $98 \mathrm{E}(1)(\mathrm{c})$

92 Section $98 \mathrm{E}(2)(\mathrm{a})$.

93 Section $98 \mathrm{E}(2)(\mathrm{c})$.

94 Section 7A.

95 Sections 98C and 98D.

96 Section 98 F. 
which a person is offered financial reward for travelling to New Zealand to 'donate' their organ, nor a situation in which a New Zealander travels to another state to procure an organ. The Crimes Act does not adequately address the crime of organ trafficking as a standalone concern. If not attached to an incidence of organised crime, human smuggling or trafficking, it does not appear to be a crime. This means that although morally repugnant, facilitating organ trafficking for financial gain may go unchecked.

The United Kingdom Human Tissue Act 2004 (UKHTA) specifically prohibits commercial dealings in human material, with an entire part of the Act dedicated to 'Trafficking'. ${ }^{97}$ Under the UKHTA, a person commits an offence if they "give or receive a reward for the supply [of organs]"98 or "seeks to find a person willing to supply any controlled material for reward"99 or "offers to supply...for reward". 100 New Zealand, and other states, should amend their legislation using this model, and extend its extraterritorial provisions to cover New Zealanders who travel overseas to procure illegal organs, as the current general prohibition under s 56 of the Human Tissue Act 2008 (HTA), which states "no person may require or accept, or offer or provide, financial or other consideration for human tissue" ${ }^{101}$ suffers from being too general.

Further, criminal responsibility should fall on medical professionals involved in the procedure. Medical staff involved in the follow up care of patients who have purchased organs should be accountable if they fail to alert authorities. ${ }^{102}$ Mandatory reporting requirements should be adopted for doctors who suspect the organs they receive for transplants are products of trafficking. ${ }^{103}$ Failing to report a suspected instance of organ trafficking perpetuates the cycle of exploitation. The law should recognise and reflect the role of doctors in the organ trafficking chain. ${ }^{104}$

97 Human Tissue Act 2004, s 32. See Appendix 3 for the full text of this provision.

98 Section 32(1)(a).

99 Section 32(a)(b).

100 Section $32(1)(c)$.

101 Human Tissue Act 2008, s 56. See side by side comparison of the provisions in Appendix 3.

102 Teagarden, above n 57, at $728-9$.

103 Glaser, above n 14, at 20.

104 At 22. 
Criminal prosecutions against members of the medical profession are rare. ${ }^{105}$ Section 61 of the Crimes Act protects medical professionals who, in certain circumstances, perform surgical operations without consent, against criminal liability. Every one is protected from liability if the performance of the surgical operation was "reasonable" having regard to the circumstances, and was performed "for [the patient's] benefit". ${ }^{106}$ Organs removal of a trafficking victim is unlikely to be "for his (or her) benefit", thus removing the protection of $\mathrm{s} 61$. Section $61 \mathrm{~A}(1)$ affords further protection from criminal liability: ${ }^{107}$

Every one is protected from criminal responsibility for performing with reasonable care and skill any surgical operation upon any person if the operation is performed with the consent of that person, or of any person lawfully entitled to consent on his behalf to the operation, and for a lawful purpose.

The definition of "lawful purpose" is neither given in this section, nor in the interpretation section of the Crimes Act. ${ }^{108}$ However, it is unlikely that a surgical operation for the purpose of removing the organ of a trafficking victim meets the consent requirement. ${ }^{109}$ Further, removal of organs as a consequence of human trafficking is a crime under s $98 \mathrm{D}(1)$, and is thus not a "lawful purpose". ${ }^{110}$

The Crimes Act arguably does impose sanctions on medical professionals who transplant organs procured illegally, but the sections relating to criminal responsibility of medical professionals are not aimed at organ trafficking, and are difficult to apply. New Zealand should clarify the criminal responsibility of medical professionals who facilitate organ trafficking.

\section{Improving the Supply and Allocation of Organs Locally}

The WHO has called for the adoption of a new paradigm, called national selfsufficiency, that involves governments taking national-level responsibility in fulfilling the organ donation and transplantation needs of patients, by accessing resources from within the state's population. ${ }^{111}$ Further, the Declaration of Istanbul on Organ

105 David Collins Medical Law in New Zealand (Brooker \& Friend, Wellington, 1992) at [7.1.1].

106 Crimes Act 1961, s 61.

107 Section 61A.

108 Section 2 is the interpretation section.

109 See Part IID of this paper for discussion of consent.

110 Crimes Act 1961, s 98D.

111 World Health Organisation Human organ and tissue transplantation WHA63.22 (2010). 
Trafficking and Transplant Tourism (the Declaration) ${ }^{112}$ encourages each state to strive to both ensure that programs to prevent organ failure are implemented and to provide organs to meet the transplant needs of its residents from donors within its own population. States should do so in order to avoid unethical practices of transplant tourism and organ trafficking arising from the global shortage of organs for transplantation. ${ }^{113}$ To that effect, principle 5 states: ${ }^{114}$

Jurisdictions, countries and regions should strive to achieve self-sufficiency in organ donation by providing a sufficient number of organs for residents in need from within the country or through regional cooperation.

The Declaration represents the standards of best practice agreed upon by participants of the Summit, but is not binding at international law. ${ }^{115}$

Self-sufficiency requires comprehensive national organ procurement programmes that include a framework of national legislation with regulatory oversight, a programme of deceased donation integrated into the national health system, with resources that sustain the system, ethical practice of live donation that ensures donor safety, and a commitment to preventive medicine that will decrease the growth of patients with end-stage organ failure. ${ }^{116}$ Without such a change, patients will continue to seek illegal and unethical organ transplants in remote parts of the world but return home for complicated medical care. ${ }^{117}$ Each state within the international community should focus its resources on domestic measures instead of waiting for international law to respond. If each state harmonises their domestic organ procurement systems, the international shortage of organs will be cohesively addressed. New Zealand should bring its organ procurement system in line with states with proven increases in organ donation; that is, states with presumed consent.

112 The Declaration was the result of the 2008 International Summit on Transplant Tourism and Organ Trafficking, convened by the Transplantation Society and the International Society of Nephrology.

113 The Transplantation Society and International Society of Nephrology "Declaration of Istanbul on Organ Trafficking and Transplant Tourism" (declaration made at the International Summit on Transplant Tourism and Organ Trafficking, April 2008), Preamble.

114 Principle 5.

115 The 160 participants at the Summit came from across states, but did not act in an official capacity.

116 F L Delmonico and others "A call for government accountability to achieve national selfsufficiency in organ donation and transplantation" (2011) 378 The Lancet 1414 at 1414.

117 At 1417. 


\section{Proposed Domestic Solutions}

This Part will discuss and analyse proposed domestic solutions for increasing the supply of organs for transplantation. States should not rely on international solutions. States must be aware that failure to satisfy demand for organs domestically has international ramifications; demand and supply forces have ripple effects for the global organ shortage. ${ }^{118}$ It is the responsibility of individual states to counter organ trafficking through domestic legislation, as meeting the demand locally and legally disincentivises organ trafficking and transplant tourism. ${ }^{119}$ While the causal relationship between domestic organ donation systems and the black market in organs may not always be clear cut, nevertheless current systems are not fulfilling their potential for organ procurement. States, including New Zealand, must consider whether they are implicitly facilitating the black organ market. Although many states express a desire to increase organ procurement, legislative action is often slow, occurring only in the aftermath of medical scandals. ${ }^{120}$ Ameliorating organ trafficking through increasing local supply should remain rooted in the theoretical arguments for altruism already outlined.

Frequently discussed models for organ procurement include conscription, mandated choice, informed consent (or 'opt-in'), soft presumed consent, hard presumed consent and non-financial incentives. Both forms of presumed consent are commonly referred to as 'opt-out' systems. Conscription, mandated choice and both presumed consent variations relate only to deceased donation, while non-financial incentives may apply to both deceased and living donation. This paper's preferred approach is hard presumed consent.

\section{A Conscription}

Under conscription, individuals are conscripted into donation prior to death and organs are harvested upon death. The wishes of the decedent and their family are

118 Williams, above n 43 , at 321.

119 Glaser, above $\mathrm{n} 14$, at 21.

120 Williams, above n 43, at 330. For example, the United Kingdom Human Tissue Act 2004 was a direct response to the Alder Hey hospital scandal, where over 850 organs of children were removed without the consent or knowledge of parents. During the Second Reading Minister for Health Rosie Winterton noted, "the aim of this legislation is to ensure that it will not happen again." 
immaterial; the organs are simply transferred to the pool of potential recipients. ${ }^{121}$ The advantage of conscription is that the efficacy of cadaveric organ procurement would approach 100 per cent. Conscription requires neither traumatized families to make decisions, nor hospital staff to approach family members, thus avoiding delays that jeopardise the quality of organs, which occurs when seeking consent. It is less costly and administratively complicated, as it does not require registries or education campaigns. Further, it would satisfy distributive justice because all people with usable organs would share the burdens as well as the benefits of organ procurement and transplantation; there would be no possibility of exploitation of one group for the benefit of another. It is an honest policy, as every citizen would know what was expected in terms of organ transplantation. ${ }^{122}$

However, a conscription system carries strongly coercive connotations. Public opposition would be difficult to overcome. Conscription entirely rejects the principle of informed consent. Conscription not only ignores consent, it shifts the rationale for organ donation from gift to duty, thereby rejecting the theoretical underpinnings that this paper considers the appropriate underlying motivation for organ donation. Compulsory donation is a contradiction; the nature of donation is not compatible with state coercion. ${ }^{123}$

\section{B Mandated Choice}

Mandated choice requires all citizens to make a definitive decision as to whether to become an organ donor, and register their choice on a national registry. The infringement on personal autonomy is only to the extent that citizens would be required by the state to make a decision. The benefits of mandated choice systems include the enhancement of individual autonomy since each person's actual wishes would be known and followed. This system would also eliminate the loss of organs through procrastination, because people would be required to confront the issue of their own deaths earlier. However, mandated choice would have to be implemented in

121 Andrew C MacDonald "Organ Donation: The Time Has Come to Refocus the Ethical Spotlight" (1997) 8 Stan L \& Pol'y Rev 177 at 181.

122 Aaron Spital "Conscription of Cadaveric Organs for Transplantation: Neglected Again" (2003) 13 Kennedy Institute of Ethics J 169 at 171.

123 Judith Sander "Organ Donation in New Zealand - A Reform Proposal for the Human Tissue Act 2008" (LLM Research Essay, Victoria University of Wellington, 2011) at 11. 
conjunction with operational changes within the medical community. ${ }^{124}$ Medical staff would have to ensure that the decedent's expressed wishes were followed, instead of obtaining family consent, which is the default response of many medical professionals. Otherwise the number of organs that would be available under mandated choice would be depleted by some of the same forces that frustrate the optin system.

Mandated choice is a middle ground between opt-in systems and opt-out systems. The fact that the state requires a decision is arguably less problematic than presuming consent unless an objection has been registered. It may be argued that presumed consent systems prey on the apathetic, whereas mandated consent only requires the apathetic to make a one decision. However, this paper considers that presumed consent is preferable; while it involves many of the same institutional changes that mandated choice requires, such as developing a register, presumed consent goes a step further, in changing the culture of organ donation. The problem with mandated choice is that it forces a decision at one particular point, such as when a person is filling out a hospital form or applying for a driver's licence. At this point, the decision may not be fully considered. If this decision is later seen as binding, it also preys on the apathetic; those who do not engage with the process or do prior research and instead simply tick a box. Mandated choice does nothing to change the motivations of would-be organ donors and may not necessarily convince people to donate their organs for altruistic purposes. It merely pressures them to make a decision. ${ }^{125}$ On the other hand, presumed consent may catalyse a significant shift in organ donation culture, and has proven to increase organ donation rates.

\section{Opt-In}

The default system for many states is the opt-in system. Opt-in means that an individual must actively express an informed wish to donate - to 'opt-in'. New Zealand's current opt-in system is detailed in Part VII. The term 'opt-in' is often used interchangeably with informed consent. However, this paper considers that this is a misuse of the informed consent principle. Opt-in systems may not always give effect to an individual's wishes. A fully realised system of informed consent would employ a

124 Macdonald, above n 121, at 183.

125 Amitai Etzioni "Organ Donation: A Communitarian Approach" (2003) 13 Kennedy Institute of Ethics $\mathrm{J} 1$ at 2. 
national "opt-in" register. Everyone would be required to make an informed decision about whether he or she wanted to become a donor if the circumstances arose and have it recorded and witnessed in a legally binding way. Under such a system, the family's wishes should not play a role, as the donors themselves would have made their own decisions in advance. The organisational obstacle to a fully effective informed consent system is that it is impractical to require everyone to make choices in advance and then efficiently keep track of those decisions. ${ }^{126}$ In practice, opt-in systems default to the wishes of family members. The informed consent of the deceased may not be respected at all. For opt-in to be effective, first the deceased must have expressed a wish either to donate or not and have made recorded this wish in writing, or expressed it clearly to their family. Secondly, medical professionals must be informed of such a wish and be prepared to carry it out, even if the family objects. In practice, this is often not the case, as medical professionals may be reluctant to ignore the wishes of the family during a traumatic time. The ineffective and inconsistent application of the so-called 'informed consent' system is a key factor in the failure of states, including New Zealand, to procure organs for transplantation.

\section{Non-financial incentives}

Short of paying potential donors for organs, another approach is to offer non-financial incentives. Examples of non-financial incentives are preferential access to organs for the donor or the donor's family, recognition of the donation, or funeral expenses (which are arguably non-financial as they are not given directly in exchange for an organ). A New Zealand example of a non-financial incentive is the non-profit organisation LifeSharers New Zealand, in which members promise to donate their organs upon death and give fellow members first access to their organs. ${ }^{127}$ By offering organs to other organ donors first, an incentive for non-donors to become donors is created. ${ }^{128}$ Non-financial incentives escape the accusations of market exploitation by falling just short of controversial financial exchange for organs. However, the potential donor is still making an exchange for their donation, defeating the altruistic basis for organ procurement.

126 Kieran Healy "Do Presumed Consent Laws Raise Organ Procurement Rates?" (2006) 55 DePaul L Rev 1017 at 1022.

127 LifeSharers New Zealand "How LifeSharers Works" < lifesharers.org.nz>.

128 LifeSharers New Zealand "How LifeSharers Works" < lifesharers.org.nz>. 


\section{E Presumed Consent}

Presumed consent is an 'opt-out' system applying to deceased donations that presumes everyone is a donor unless they take affirmative steps to register their objection to organ donation. There are two types of presumed consent systems: 'soft' presumed consent and 'hard' presumed consent. Hard presumed consent systems are more likely to increase organ supplies to meet demand. The wishes of the deceased's family are neither considered nor requested in a hard presumed consent system. In soft presumed consent systems, the wishes of the family may be taken into account, and may be determinative, regardless of the deceased's wishes. ${ }^{129}$ Soft presumed consent systems are in essence the same as opt-in systems because the family may still object. ${ }^{130}$ Many European states have a system of presumed consent, including France, Spain, Austria, Italy, Sweden and Belgium. ${ }^{131}$ In Belgium less than 2 per cent of the population has elected to opt-out, which they may do by registering their objection at any town hall. ${ }^{132}$

There are three ways that presumed consent might be associated with higher procurement rates. First, hard presumed consent laws allows for all potential donors who have not registered an objection to become real donors, with no loss due to refusals by family members. Timing is critically important to organ and tissue harvesting; most viable tissues require harvesting within three to six hours of death. ${ }^{133}$ So long as the deceased donor has not registered an objection, hard presumed consent allows transplant to proceed without waiting for other possible objections. ${ }^{134}$ However, almost all countries with presumed consent laws have soft presumed consent, allowing family members to be consulted. Austria is the only true hard presumed consent system. ${ }^{135}$ However, even soft presumed consent may increase

129 Statz, above n 18, at 1690.

130 Glaser, above n 14, at 21.

131 Alberto Abadie and Sebastien Gay "The impact of presumed consent legislation on cadaveric organ donation: a cross-country study" (2006) 25 Journal of Health Economics 599 at 599 -

600. See also Rithalia and others, above n 3 and Sjef Gevers, Anke Janssen and Roland Friele "Consent Systems for Post Mortem Organ Donation in Europe" (2004) 11 EJHL 175 which compares 10 systems in force in Europe: Austria, Belgium, France, Germany, Italy, the Netherlands, Spain, Sweden, Switzerland and the United Kingdom.

132 Richard Howard "How Can We Increase the Number of Organ and Tissue Donors?" (1999) 188 J Am Coll Surg 317 at 323.

133 Michele Goodwin Black Markets: The Supply and Demand of Body Parts (Cambridge University Press, New York, 2006) at 132.

134 At 132.

135 Healy, above n 126, at 1028. 
organ donations, because presumed consent laws function as a signalling device to the population in general and family members in particular. Having a presumed consent law shifts the question facing donors and their families. Rather than being asked, "Can we have your permission to go ahead?" families are instead asked, "Do you have any reason to think the donor would have objected?"136 This is a small but significant shift. In terms of public opinion, presumed consent would express a social norm or expectation about the default course of action. Donation is still a choice, but saying "yes" is assumed to be the standard option, rather than a special decision for which consent must be specially sought. Family members are no longer the default decisionmakers ${ }^{137}$ and the decision as to whether or not to donate organs is not made during the grieving period immediately following death. ${ }^{138}$ Finally, presumed consent laws lead to higher procurement rates because they require effective registration systems and are associated with better institutional practices. Rather than being a causal force in themselves, presumed consent systems may simply be markers for other practices that make organ procurement more efficient. ${ }^{139}$

The overwhelming objection to presumed consent is that it infringes on individual autonomy and goes against the fundamental medical principle of informed consent. This objection assumes that an individual has no autonomy or choice in the matter at all; that organs will be procured by the state in all circumstances. In fact, the presumed consent system is a stronger indicator of a potential donor's wishes. If a person is strongly opposed to donation, presumably they would take the steps to optout, signaling to their family their wishes. In an opt-in system, apathy is rampant, and family members are often unable to make quick decisions at the hospital. Although soft presumed consent may in practice be similar to opt-in systems, the culture created by having to opt-out arguably allows for more consistent implementation of the potential donor's wishes.

The terminology used to describe presumed consent is confusing. Presumed consent is commonly described as 'opt-out' and is contrasted to 'opt-in' systems, which is used interchangeably with informed consent. Such terminology appears to place presumed consent at irreconcilable odds with informed consent. However, so long as presumed

136 Healy, above n 126, at 1028

137 At 1028

138 Glaser, above n 14, at 21.

139 Healy, above n 126, at 1029. 
consent is implemented alongside factors to be discussed below, such as public education and institutional safeguards, a potential donor will still receive all the information concerning the process of organ transplantation required for the donor to make an informed decision. Informed consent is still present in the decision not to opt-out; and as a corollary, if an individual does choose to opt-out, they will be provided with all the information necessary to make an informed objection.

Fears that presumed consent preys on the apathetic can be allayed if states that adopt presumed consent systems simultaneously commit to public education campaigns. The option to object to organ donation should be made clear to citizens; this would also ensure that family are aware that the donor made an informed decision to donate. ${ }^{140}$ Another way to ameliorate potential infringement on an individual's choice to donate organs is through creating specific national bodies to regulate and provide easily accessible processes for opting out. If anything, presumed consent (particularly hard presumed consent) allows for increased personal freedom because it makes sure that an individual's wishes are actually carried out, rather than circumvented by the family's choices. ${ }^{141}$ Presumed consent has been criticised for assuming that organs belong to the state or society rather than to individuals or families. However, properly understood, presumed consent merely shifts the presumption about an individual's wishes in the absence of express statement of those wishes, after adequate opportunity for objection is given. ${ }^{142}$

\section{Presumed Consent in Practice}

At first glance, a comparison of presumed consent states to non-presumed consent states reveals that states following presumed consent models have higher levels of donation. Austria, a presumed consent state, shows higher rates of organ donation than Germany, a non-presumed consent state, even though their cultures are very similar. ${ }^{143}$ However, factors that affect presumed consent and may significantly influence donation rates include the presence (or lack) of institutional processes, the

140 Glaser, above n 14, at 22.

141 Statz, above n 18, at 1698.

142 James F Childress "Ethical Criteria for Procuring and Distributing Organs for Transplantation" (1989) 14 J Health Polit Policy Law 87 at 96.

143 As seen in a 2003 study, Germany uses an opt-in system and has an organ donation consent rate of $12 \%$, whereas Austria has an opt-out system and has an organ consent rate of $99.98 \%$. See Eric J Johnson and Daniel Goldstein "Do Defaults Save Lives?" (2003) 302 Science 1338. See also Rithalia and others, above n 3. 
role of the family, public education and cultural and religious factors. ${ }^{144}$ The next Parts discuss factors influencing the successful implementation of presumed consent. The role of culture is discussed in detail in the New Zealand section.

\section{A Institutional Processes}

A national register is fundamental to the success of presumed consent. The arguments against presumed consent can only be countered if a register in is place that records each individual's informed objection to donation. The register would only need to record opt-outs, as everyone else is presumed to consent to donation. Thus, concerns about the costliness of maintaining a nationwide register would be alleviated; as such a register does not require records of a state's whole population.

Secondly, optimising deceased organ donation requires a central structure of transplant organisations or specifically trained hospital staff to be involved in the process. Donation is more likely to occur when the request for donation is made by trained staff, as can be seen in the Spanish example below.

Thirdly, the number of beds in an intensive care unit (ICU) of hospitals may impact organ procurement. Deceased donors are declared brain dead while their body and vital organs are supported by artificial means. ${ }^{145}$ The number of deceased donors eligible for donation depends upon the capacity of ICUs. Increasing intensive care facilities means that hospitals are open to more potential deceased donors. There are comparatively few intensive care beds in New Zealand, due to the practice of limiting intensive care if patients are considered to have a poor prognosis, to avoid blocking beds for patients more likely to benefit from intensive care. This restricts the donation rate. ${ }^{146}$ However, this practice could be changed to reflect a change in policy with presumed consent.

\section{$1 \quad$ Spain}

Spain provides an illuminating example of the significance of institutional processes. Spain is frequently cited as an example of successful presumed consent. Spain has

144 Statz, above n 18, at 1697.

145 Jennifer J Howard "Fatal Flaws: New Zealand's Human Tissue Act Fails to Provide an Avenue for Individuals to Give Legally Binding Informed Consent" (2013) 22 Pac Rim L \& Poly J 209 at 213.

146 Thomas, above n 30, at 42 . 
had a presumed consent system for organ donation since 1979. A recent report notes that organ donations have increased by 142 per cent since $1989 .{ }^{147}$ The organ donation rate for deceased donors in 2011 was 35.1 per million people. ${ }^{148}$ Reports of the Spanish case suggest that improved donation rates are due to substantial investment in the logistics of organ procurement, better training, clear delegation of responsibility and a strong presence in hospitals, rather than simply a change in the legal structure of donation or a wholesale change in public opinion. ${ }^{149}$

A multi-layered coordination network is the basis for the Spanish model. Spain has developed a network of transplant coordinators across 139 ICUs. ${ }^{150}$ The trained transplant coordinators are physicians who are part of the in-house staff of the hospital, but are completely independent from the transplant team. They play an active part in coordinating all aspects of the organ donation process, particularly in discussing organ donation with the family of the deceased, taking away the burden of organ procurement from the transplant surgeons. ${ }^{151}$ The professional skills and training of these coordinators are a key part of this model. ${ }^{152}$ Spain has developed a policy of 'active detection'. Active detection means that trained transplant coordinators visit emergency rooms and ICUs on a daily basis, checking the status of patients, and identifying potential donors. The coordinators also discuss the donation process with families. A survey by Spanish researchers found that of 200 families who originally objected to donation, 78 per cent changed their minds after speaking with a transplant coordinator. ${ }^{153}$ There are no financial incentives for transplant coordinators to identify potential donors or to increase the donor rate from their hospital. ${ }^{154}$

The Spanish example highlights the fact that dynamic growth in procurement rates is the result of a presumed consent system coupled with infrastructural investment and organisational reform. Spain stands out not because it offers incentives for donors or

147 Teagarden, above n 57, at 725.

148 Organ Donation New Zealand "Statistics" <www.donor.co.nz>.

149 Healy, above n 126, at 1041.

150 Statz, above n 18, at 1695; Teagarden, above n 57, at 726.

151 John Fabre "Presumed consent is unnecessary" (2010) 341 BMJ 922 at 923.

152 Sander, above n 123, at 21.

153 Teagarden, above n 57, at 726.

154 Fabre, above n 151, at 923. 
their families but because of its presumed consent system, accompanied by effective institutional processes that encourage increased altruistic donation. ${ }^{155}$

\section{Brazil}

In contrast to Spain, Brazil is an example of a failed presumed consent system. In January 1998, Brazil enacted a law declaring all adults potential organ donors unless they filed for an exemption, but did not have the resources to implement any of Spain's institutional structures. ${ }^{156}$ In October 1998, the Brazilian government repealed the presumed consent law, in response to opposition from the Brazilian Medical Association, the Federal Council of Medicine and the general public. ${ }^{157}$ The law was ineffective because most doctors were unwilling to harvest organs against the wishes of family members even though the law required them to do so. The lack of infrastructure needed to maintain the intended register of recipients, as well as the inability to transport the organs between hospitals all contributed to the failure of the system in Brazil. ${ }^{158}$ Without support from medical organisations and against a background of public distrust of the government and negative media reports, the Brazilian presumed consent system could not stand. ${ }^{159}$

The problem in Brazil stemmed from incompetent administration and lack of infrastructure rather than a defect in the law itself. ${ }^{160}$ The case studies of Spain and Brazil offer salutary lessons for the implementation of a presumed consent system in New Zealand, showing the importance of institutional safeguards and infrastructure.

\section{B Role of Family}

The role of family members complicates both presumed consent and informed consent systems. As already discussed, if almost all presumed consent systems in fact allow the family to refuse consent for donation, they are the same as opt-in systems

155 Healy, above n 126, at 1042.

156 Troy R Jensen "Organ Procurement: Various Legal Systems and their Effectiveness" (2000) 22 Hous J Intl L 555 at 559. Various legal systems of organ donation

157 At 572; Claudio Csillag "Brazil abolishes presumed consent in organ donation" (1998) 352 The Lancet 1367 at 1367.

158 Jensen, above n 156, at 573.

159 Rithalia and others, above $\mathrm{n} 3$, at 36.

160 Jensen, above n 156, at 565. 
and the change in law allowing medical staff to override the wishes of families during donation will have minimal effect on increasing procurement rates. ${ }^{161}$

The question of whether the family of a deceased person should be granted the right to veto the deceased's decision to become an organ donor is a controversial one, not least in the New Zealand context. The first draft of the Human Tissue Bill 2006 contained the right of families to override the deceased's wishes in exceptional circumstances. This was removed from the final version of the HTA. ${ }^{162}$ Families often refuse to give consent because they are not sure of the deceased person's wishes. However, if the wishes of the deceased are known, the family's decision is typically consistent with the recorded wish. ${ }^{163}$

Common misconceptions or psychological barriers often drive refusal to donate when the family is approached. Misconceptions include a family's fear of inadequate healthcare provided to donors and general avoidance of thinking about death. The primary psychological barrier is the traumatic experience of losing a family member; this can prevent the family from making an informed, rational decision regarding organs. ${ }^{164}$ A family is more likely to agree to donate if misconceptions are dispelled through public education and campaigns that facilitate discussions among family members.

\section{Public Education}

An essential element of any organ donation system is public education. Public education must go hand in hand with presumed consent. Public education encompasses both specific information about how the organ donation system works, and more generally the benefits of altruistic organ donation. In the latter case, more generalised public education about altruistic donation may also function as an independent mechanism for encouraging increased organ donations. Public education also increases public confidence in the healthcare system, which in turn may encourage more donations. Governments should be actively involved in promoting and financing public education to provide their citizens with a better chance of receiving organ transplants.

161 Healy, above n 126, at 1025.

162 Sander, above n 123, at 20.

163 At 20.

164 Howard, above n 145, at 219. 
On a specific level, public education raises awareness about the workings of the presumed consent system, and how an individual can register their objections if they wish. On a general level, public education seeks to increase organ donation by improving public awareness of transplantation and of the need for organ donation so that individuals will be consider donating and talk to their family members about organ donation. Hospitals and government health ministries should work to produce a public understanding of why donation is worthwhile. ${ }^{165}$ An important aspect of high donor states is a culture where donation is the norm and the expectation that someone will donate is shared throughout the community. ${ }^{166}$ A culture of donation ameliorates the ethical concerns suffered by presumed consent; it is not seen as coercive and unethical if the community already considers donating to be the norm and expects to have to take extra steps to opt-out. This may incorporate educating in schools from a young age. Education programmes for young persons should highlight the fact that organ donation is an act people engage in altruistically because they consider it their social responsibility, akin to volunteering. ${ }^{167}$ It is important to design programmes that encourage conversation between family members from a young age, as well as informing people about the importance of organ donation. Such discussions are critical and have implications for all involved in the organ donation process, regardless of the characteristics of the organ donation system in which they are involved. ${ }^{168}$

Education must also extend to health professionals. The promotion of learning from one another and increasing adequacy of training to all professionals involved in the promotion of organ donation should be a priority of this international cooperation. The organisational approaches of areas with high donation rates need to be studied carefully. Educational programmes should be established where the staff from high procurement areas are used to train individuals from areas of lower procurement. ${ }^{169}$ Approaches and attitudes of hospital staff are important in organ donation. A goal of hospital education and development should be to encourage hospital staff to take ownership of the process to help support organ donation from within the hospital.

165 Healy, above n 126, at 1019

166 Howard, above n 145, at 230.

167 Etizoini, above n 125, at 5.

168 M R First "Cadaveric Organ Procurement - An Overview of Two Aspects: Donor Hospital Networks and Minority Donation" (1997) 29 Transplantation Proceedings 70 at 70 .

169 At 71. 
California provides an example of a successful public education campaign. Donate Life California launched a broad education campaign in 2005 with the aim of lifting organ donation rates. Its listed aims were to: ${ }^{170}$

- Redefine and reposition organ donation as a public health problem for Californians;

- Educate the public and media about the lack of organ donors;

- Spread awareness using community collaboration and media advocacy strategies and;

- Adopt a single call to action compelling Californians to become organ donors by registering online.

The strategy hinged upon providing information to hospitals, families of potential organ donors, and the community. More than 175,000 new donors joined the online registry during the first 6 months of the campaign. ${ }^{171}$

In order to truly give effect to presumed consent, this paper argues first, that states should implement hard presumed consent rather than soft presumed consent, and secondly, there must be a shift in medical practice. Medical professionals should first consult the stated wishes of the deceased, rather than going straight to the family. Such a shift requires effective institutional processes, including a national register and directed public education, with a focus on encouraging conversations amongst families about organ donation.

\section{Can Presumed Consent Work in New Zealand?}

The Human Tissue Act 2008 (HTA) specifically legislates for informed consent in human tissue and organ donation in New Zealand, replacing the Human Tissue Act 1964. Under s 19(1)(a), collection or use of human tissue that is collected from a body must be done with informed consent. ${ }^{172}$ Under s 31 , informed consent may be given by before death by the individual from whose body the tissue is collected, the

170 Helen Allrich, Elizabeth Dougall and David Heneghan "Donate Life California: A Campaign Launch Case Study" (2007) 1 Cases in Public Health Communication \& Marketing 1 at 1.

171 At 1 .

172 Human Tissue Act 2008, s 19(1)(a). 
individual's nominee, a member of their immediate family or a close relative. ${ }^{173}$ Informed consent for the collection or use of human tissue is defined as consent: ${ }^{174}$

(a) to that kind of collection or use of the tissue (and so does not include agreement in general terms, given by an applicant for, or holder of, a driver licence, to that applicant or holder being an organ donor); and

(b) given by a person who is entitled to give it under subpart 3; and

(c) given freely, and in the light of all information that a reasonable person, in that person's circumstances, needed in order to give informed consent.

There is currently no presumption in New Zealand that the deceased will be an organ donor; there must be explicit consent on the part of the donor, in a will or an advance directive, or made orally in the presence of two witnesses. ${ }^{175} \mathrm{~A}$ common misconception is that being listed as a 'donor' on a New Zealand driver's licence constitutes consent to donation. In fact, that is not legally binding. In the absence of a will or advance directive, or witnessed oral statement, consent to donation defaults to the family members. ${ }^{176}$

While the Human Tissue Bill 2006 (HTB) was before the House of Representatives, a concurrent bill, the Human Tissue (Organ Donation) Amendment Bill 2006 (Organ Donation Bill) was also being heard. The Organ Donation Bill, a private members' bill that proposed a national organ donation registry, did not pass its second reading. The Health Committee considered the HTB sufficient to regulate organ donation matters. Thus the HTA is the only governing statute for cadaveric organ donation in New Zealand. It is worth noting that the HTA primarily regulates cadaveric donation, although the s 56 provision against exchange of organs for financial gain applies to both deceased and living donation. ${ }^{177}$ It is interesting to note that in the debates around both bills, opt-in was the dominant approach to organ donation; in fact, presumed consent was not discussed at all. The next Part discusses the matters considered by the House in the process of debating the two bills. The matters discussed offer insight into the main concerns in organ donation in New Zealand.

173 Section 31(2)(a) - (d). For a helpful flowchart, see Appendix 3.

174 Section 9.

175 Section 43.

176 See Appendix 3 flowchart.

177 Section 56 


\section{A Human Tissue (Organ Donation) Amendment Bill 2006}

The main proposal of the bill was a national organ register. The register was to take the form of an opt-in register for individuals to indicate which organs they wish to donate, and whether the organs would be used for therapeutic use or for medical educational research. The register would record objections for individuals to register a clear instruction not to donate in any circumstances. Most significantly, the bill allowed for the wishes of the donor to be paramount, with binding legal status. ${ }^{178}$

In introducing the bill, MP Jackie Blue noted: ${ }^{179}$

Importantly, provision is also made for public education regarding organ donation. Countries with established organ donor registers that have resulted in an increase in organ donors link their success directly to education and publicity.

Blue also highlighted the persistent calls for change and the dropping organ donation rates in New Zealand, noting that in 2002 Andy Tookey and 1,169 others presented a petition to Parliament that requested a review of organ donation practices. The Health Committee tabled reports in November 2003 and October 2004 that requested urgent action to improve New Zealand's organ donor shortage and provided information on how an organ donor register might work, but no further reform materialised. ${ }^{180}$

The bill faced resistance on two fronts: first, there was debate as to the efficacy of a national register and secondly, concern that the bill's focus on the individual's wishes would not reflect tikanga Māori. The importance of incorporating tikanga Māori was acknowledged in the bill. The role of whānau was highlighted in the organ donation process. ${ }^{181}$ The Māori perspective was further emphasised by Tariana Turia, who stated: 182

Human tissue organ donation is a massive issue for us, and it raises huge questions about issues of protection, informed consent, tangata whenua control of information and medical processes, access to information and medical care, and, most of all, cultural respect.

178 (3 May 2006) 630 NZPD 2748.

179 At 2748.

180 At 2748 .

181 At 2753.

182 At 2754. 
Despite the strong support for amendment of the organ donation system and concern for dropping organ rates, the Health Committee recommended that the bill not be passed, noting that compelling evidence for a legally binding register was not available at this time. However, the Committee recommended the inclusion of a clause in the Government's Human Tissue Bill to permit the establishment of an optin organ and tissue donor register, should the evidence make that a desirable course in the future. The Committee acknowledged that evidence did point to increased public awareness about organ and tissue donation, improvements in processes around donation, and improvements in coordination between agencies as being most likely to lead to improvements in donation rates. The Committee considered that Organ Donation New Zealand had sufficient initiatives under way in this area. ${ }^{183}$

\section{B Human Tissue Bill 2006}

The HTB provided a framework for regulating the collection, storage, and use of tissues and organs, primarily from the deceased as well as regulating trade in tissue, export and import of tissue, and the use of tissue for non-therapeutic purposes-for example, audit, research, and post-mortem. ${ }^{184}$ The bill also clarified the consent framework for organ and tissue donation, especially the role of family members in giving consent. ${ }^{185}$ The stated purpose of the bill was to make informed consent the fundamental principle underpinning the lawful collection and use of human tissue from deceased people, to ensure that autonomy and dignity of the individual is respected, as well as cultural and spiritual needs. ${ }^{186}$ The bill allows for both informed consent and informed objection. ${ }^{187}$

The HTB passed into law, without providing for a national organ registry. The HTA includes a provision for future implementation of a national register, which to date has not materialised. ${ }^{188}$ The fact that the Organ Donation Bill did not pass a second reading offers a pessimistic outlook for presumed consent in New Zealand. If an optin register could not gain the support of Parliament it appears unlikely that an opt-out system could ever gain the support of Parliament. Although the two bills discussed

183 (7 November 2007) 643 NZPD 12900; see also Human Tissue Bill (82 - 2) (select committee report).

184 (14 November 2006) 635 NZPD 6467.

185 At 6467.

186 At 6467 - 8; Human Tissue Bill (82 - 2) (select committee report) at $1-2$.

187 Human Tissue Act 2008, s 14.

188 Section 78. 
above indicate the difficulty of implementing presumed consent in New Zealand, the system is still worthy of consideration, for the reasons already discussed. New Zealand is implicated in the organ shortage through its low numbers of organ donators. The shortage may be even more problematic than it appears at first glance, because transplantation waitlists in New Zealand do not reflect the true number of patients in need of organs. Many people whose bodies have deteriorated past the point of being healthy enough to receive an organ are removed from the waitlist. ${ }^{189}$ There remains a pressing need to address the issue of organ shortages in New Zealand, which the HTA does not adequately address.

The HTA creates a strong framework for physicians and organ procurement specialists to obtain informed consent and thus uphold individual autonomy, but fails to create a way to provide this consent easily. It is difficult for hospital staff in an emergency situation to ascertain whether consent has been given orally in the presence of witnesses or through a will or advance directive. ${ }^{190}$ Without an easy way for someone to create binding informed consent or select a nominee, the law leaves organ procurement staff to sort through complicated family structures to discover whether someone capable has provided the proper consent. ${ }^{191}$ If any member of the family objects, the transplant surgeon will not go ahead with the organ removal. It is unlikely that a hospital staff will sort through who has higher priority for decisionmaking based on the HTA, especially as organ donation has a time limit. ${ }^{192}$

A medical professional who collects organs without the appropriate informed consent may face fines or imprisonment. However, should the professional refuse to take an organ for any reason, even if informed consent has been given they are protected. This tips the scale against taking organs should a physician believe there could be a claim that informed consent was not properly obtained or that a valid objection has been raised. ${ }^{193}$ As the HTA provides no means of registering the wish to donate, it allows organ donation rates to stagnate. This does nothing to combat the international organ shortage, and does not fulfil New Zealand's responsibilities of reducing organ

189 Howard, above n 145, at 214. Organ Donation New Zealand "Waitlist" <www.donor.co.nz>.

190 Howard, above n 145, at 220.

191 At 220.

192 At 224.

193 Howard, above n 145, at 223; Human Tissue Act 2008, s 22(1) and s 17. 
trafficking through self-sufficiency. New Zealand should implement a presumed consent system.

\section{A Presumed Consent Framework for New Zealand \\ 1 Māori perspectives}

The HTB and Organ Donation Bill debates highlight the key consideration of tikanga Māori. It is essential to consider Māori perspectives on deceased and living organ donation in implementing a presumed consent system in New Zealand. The Treaty of Waitangi underpins the provision of health services to Māori. The Treaty partnership requires that Māori be able to protect their cultural practices and their tikanga and participate fully in NZ society as Māori. The principle of partnership under the Treaty must be given effect in health policy development. ${ }^{194}$ It should be noted that Māori beliefs are not uniform; traditional Māori beliefs vary among iwi and many Māori are detached from traditional beliefs. There is no one reality, nor is there any longer a single definition which will encompass the range of Māori lifestyles. In considering policies for Māori health, the diverse realities of Māori must be taken into account. ${ }^{195}$

Presumed consent for organ donation directly impacts on the Māori worldview, as explained by Pita Sharples, speaking to the Organ Donation Bill: ${ }^{196}$

The concepts associated with burial - the connection between birth and death-the healing, grieving, and cultural practices of iwi Māori, are deeply steeped in the sense of sanctity, of tapu and kawa...they are concepts that are essential in any discussion around organ donation, strategies to enhance health and well-being, renal disease, and the collection and use of human tissue. These issues are more than that of an individual signing a register to either confirm or object to the opportunity to be an organ donor. It is a collective process for Māori; one that is absorbed into the process of whānau decision-making.

In the Committee stage for the HTB the Māori Party proposed that families be given the power to veto the consent given by Māori individuals while they were alive. Although it was considered appropriate that cultural issues be considered during the

194 Te Puni Kōkiri Hauora o te Tinana me ōna Tikanga Service Providers (1999) at 8.

195 At 2.

196 (7 November 2007) 643 NZPD at $12906-12907$. 
organ donation process, it was not felt to be appropriate to give families a legal right to override an individual decision. ${ }^{197}$ However, the HTA requires the person collecting human organs or tissue to take into account cultural and spiritual needs. ${ }^{198}$ Presumed consent legislation in New Zealand should honour this provision.

According to a Te Puni Kōkiri report, Māori both donate and receive proportionally fewer organs than non-Māori. ${ }^{199}$ Māori are under-represented in donation statistics, while at the same time being more likely to need organ donation. The report notes that the rate of Māori dying from kidney related disease is four times that of non-Māori. ${ }^{200}$

Lewis and Pickering suggest that one possible explanation for the discrepancy between Māori and non-Māori organ donation rates are spiritual beliefs of Māori, particularly as relating to death and dying. ${ }^{201}$ From a spiritual point of view, traditional Māori beliefs offer fundamental reasons for not donating organs including the adverse impact that organ donation may have upon donors and their whānau and the adverse impact that receiving a donated organ may have upon recipients and their whānau. ${ }^{202}$ The overarching belief is that not to burying an individual whole would be seen as breaking the cycle of life back to Papatuanuku. All life is derived from the earth, and to return an individual to the earth with organs missing introduces incompleteness, leaving an unfulfilled process from birth to death, a cycle which is tapu. ${ }^{203}$

As reflected in the holistic approach of traditional Māori society, ramifications of organ donation for the individual donor also become implications for the whannau as a whole. ${ }^{204}$ The individual's body is seen as the physical manifestation of whakapapa. ${ }^{205}$ Previous generations culminate in the physical body of a person, which is only a link in the chain of whakapapa extending into the past and the future. To have parts of the body living on outside the body has ramifications for the ancestral line and harms the

197 (8 April 2008) 646 NZPD 15430.

198 Human Tissue Act 2008, s 18.

199 Te Puni Kōkiri, above n 194, at 16.

200 At 14.

201 Greg Lewis and Neil Pickering "Māori Spiritual Beliefs and Attitudes Towards Organ Donation"(2003) 4 NZ Bioeth J 31 at 32.

202 At 32

203 At 32.

204 At 33.

205 At 33. 
whānau as a whole. ${ }^{206}$ Allowing individuals to be the sole decision-makers of whakapapa does not allow for the collective involvement of whānau. ${ }^{207}$

On the part of the recipient there are also matters to consider. Whakapapa is of importance; with a foreign organ in the body, recipients are no longer made up of the material only of their tipuna or ancestors. For some recipients, this may create a feeling of alienation from whānau, iwi and tipuna. The bloodline of the whānau may be perceived as diluted or contaminated. ${ }^{208}$ Moreover, organ donation tears at the fabric of tapu, as seeking to retain the life of an individual by the removal of organs from someone who has died creates an interplay between the living and the dead that may upset the spiritual order. ${ }^{209}$ The spark of life is transferred through human will and not by divine order. These considerations may be great enough to outweigh the benefits of donating or accepting organs. ${ }^{210}$

As far as living donation is concerned, the intermingling of whakapapa remains a concern. However, living donation within a whānau may be more acceptable for some Māori as the donation is unlikely to be anonymous and uncertainty about ancestral lineage is removed. ${ }^{211}$

There is a wide range of views and attitudes about transplantation and donation within the Māori community and a blanket refusal to donate should not be assumed. Individual circumstances equally influence decisions, and all options must be explained to patients in the context of clear and understandable information about the realities of organ failure. The communication skills and cultural competence of transplant team members are critical in dispelling inaccuracies and improving outcomes for the Māori community in New Zealand. ${ }^{212}$ Any system of presumed consent in New Zealand must recognise cultural perspectives and provide processes for giving effect to cultural differences.

206 At 33.

207 Human Tissue Bill 2006 (82 - 2) (select committee report) at 8, per the Māori Party minority view.

208 Lewis and Pickering, above n 201, at 34.

209 At 34.

210 At 34 .

211 At 35.

212 Mauri Ora Associates Māori Pacific Attitudes Towards Transplantation: Professional Perspectives (Ministry of Health, October 2009) at 4. 
The same factors discussed in Part VI are applicable in the New Zealand context. The involvement of whānau is recognised as a crucial part of improving Māori health and well-being - thus education programmes and information must be developed for both Māori and their whānau about organ donation and organ transplantation. Māori patients and their whānau considering organ donation should be given as much support and time as they require to understand the concept of presumed consent and to reach an informed decision, collectively. Presumed consent gives effect to the wishes of the individual, but this does not mean that the individual should not be encouraged to discuss their choice with their family. Education programmes should encourage dialogue with whānau, so that communities can be confident that the individual's views are shared and understood by the collective family. Advanced skills for critical care professionals can be improved by training for interacting with grieving families with cultural sensitivity. ${ }^{213}$ If health care information is communicated in a way that is perceived by Māori as sensitive to their cultural beliefs and values, the likelihood of understanding, treatment compliance and improved outcomes are more assured. ${ }^{214}$

It is also important that recipients of body parts are offered an opportunity of culturally accepting the transplant, for example by having a karakia over the donated organ. This is an integral part of cultural acceptance of a transplant. ${ }^{215}$ Transplant staff should be prepared to address the entire whānau present, allow time for the whānau to discuss the issue by themselves without clinical staff present, offer to make a referral to the Māori chaplain, offer to make a referral to Whānau Care Services for a Māori advocate to provide support or to facilitate hui and to explain to whānau the presumed consent system. ${ }^{216}$

The reference group for the Te Puni Kōkiri report on organ donation commented "one hundred years ago there were no options for Māori. This is all new, Māori are beginning to look at the donation as taonga." 217 Donation can be seen as a gift of life and many patients, including Māori experience increased well-being and quality of life after receiving a transplant. The key to implementing a successful system of

213 Te Puni Kōkiri, above n 194, at 19.

214 Capital and Coast District Health Board "Tikanga Māori: A Guide for Health Care Workers" (2009) at 15.

215 Te Puni Kōkiri, above n 194, at 20.

216 Capital and Coast District Health Board, above n 214, at 21 - 22.

217 Te Puni Kōkiri, above n 194, at 13. 
presumed consent in New Zealand is by respecting cultural differences through clear dialogue and respecting the need for whānau input. Accordingly, targeted education programmes, and communication skills and cultural competence of transplant team members, will be critical in dispelling inaccuracies about presumed consent and improving organ transplantation outcomes for the Māori community. ${ }^{218}$

\section{Deceased donation opt-out registry}

Presumed consent must be paired with an opt-out registry, in order to protect individual autonomy, to allow those who wish to opt-out may do so and to ensure public confidence in the system. Pairing a national registry with a presumed consent system will increase the rate of organ donation in New Zealand and flow into the solution for organ trafficking. The systems will work concurrently to address the limitations that exist were either system to be instituted in isolation. ${ }^{219}$ To institute the registry, New Zealand will need to engage in a national awareness campaign to educate the public on the new registry and the option to opt-out and prepare them to make a legally binding decision. Informed consent will be achieved through public education. $^{220}$

The national registry would provide an easy way to register and record legally binding objection, while respecting individual autonomy and the cultural and spiritual needs of the family. The implementation of a register is already provided for in law under $\mathrm{s}$ 78 of the HTA. ${ }^{221}$ Setting up a register would not require significant policy change. The Health Committee was concerned about underutilisation, fearing that the high cost of instituting the registry would not be countered by a higher donation rate. ${ }^{222}$ This concern would be addressed under presumed consent coupled with widespread public education as to the mandatory nature of the presumption, as it would call for all New Zealanders to make a decision as to whether to opt-out. One practical suggestion for making sure the register is utilised is by requiring New Zealanders to consider whether they wish to opt-out and including an information box about how to do so on tax return forms ${ }^{223}$ or on electoral forms. ${ }^{224}$ After New Zealanders register an

218 Mauri Ora Associates, above n 212, at 9.

219 Howard, above n 145, at 226.

220 At 226.

221 Human Tissue Act 2008, s 78.

222 Human Tissue Bill $2006(82-2)$ (select committee report) at 2.

223 Howard, above n 145, at 232. 
objection to donation it would be entered onto the national registry and would be available to hospitals and organ procurement staff. At any point, an individual could change their mind about either opting-out or chose to opt-out by contracting the registry directly. ${ }^{225}$ An individual could also update their choice at the next opportunity for filing a tax form or filling out an electoral form. The reason why donation rates are so low is largely due to apathy - many people are simply waiting for someone to pose the question. ${ }^{226}$ Presumed consent accompanied by a register removes the question while at the same time providing an uncomplicated and legally binding way for individuals to register their objection; thereby giving effect to informed consent.

Public education is of particular pertinence in implementing presumed consent in New Zealand, first because of the importance of creating culturally appropriate education campaigns for Māori, and secondly, because the lack of action for public education was of particular concern during the debates for the HTB and the Organ Donation Bill. NZ First noted, "without a [public marketing] campaign, organ donation will always remain in the too-hard basket". 227 The current HTA neither increases organ donation rates, nor provides a way to register consent, even though it purports to uphold informed consent. A system based on a two-step approach of general public education and comprehensive information about the presumed consent system and how to opt-out at the time of decision-making would form the basis of informed consent as required by the HTA and the Code of Health and Disability Services Consumers' Rights. ${ }^{228}$

Further, during the debates it was affirmed "the very last thing New Zealanders would want to occur is financial consideration for human tissue or human organs...the gift status these donations have been accorded must remain."229 Thus the New Zealand system remains rooted in altruism. Although presumed consent was not mentioned as an option, some Members of Parliament did emphasise the need to "continue to think

224 Electoral Act 1993, s 82. It is already compulsory for eligible New Zealanders to be enrolled on the electoral roll, ensuring that New Zealanders would have access to presumed consent information if it the information is included on electoral forms.

225 Howard, above n 145, at 233.

226 At 234.

227 (23 October 2007) 643 NZPD 12614, per NZ First.

228 Sander, above n 123, at 18; see Part IID for discussion of the Code.

229 (8 April 2008) 646 NZPD 15434. 
laterally and creatively around what possibilities we may not have yet explored for improving donor rates within New Zealand."230 Presumed consent is one such possibility. Not only will such a system contribute on a domestic level to decreasing the demand for trafficked organs, it will also yield huge savings. Kidney dialysis imposes health care costs on the New Zealand public health system. There is a monetary incentive in improving organ donation rates, particularly of kidney donations. $^{231}$

It is acknowledged that imposing presumed consent immediately might not be acceptable to the general public. This paper suggests that a middle ground may lie in first implementing an opt-in register under s 78, coupled with a public education campaign about presumed consent. In two years' time, the register may gradually be converted to an opt-out register, in which those who have already opted-in will be asked whether they wish to remain so, everyone else who does not register an objection will be presumed to be donors. Speaking for her Organ Donation Bill Blue noted: 232

Some countries have presumed consent registers where everyone is presumed to be a donor and must physically opt off if they do not wish to be. I urge all members not to invent the wheel but to let all those countries that do well in organ donation become our model for a better system that would not only respect individuals' wishes and be kinder to grieving families but would save the lives of those who would die needlessly.

\section{Living donation}

Living organ donation will remain the same under the proposed change to presumed consent. Living donations in New Zealand are governed by the Code, and the principle of informed consent. However, this paper has proposed amendments to the HTA and the Crimes Act, which will clarify that living organ donations for financial gain are prohibited. ${ }^{233}$ The public education campaigns accompanying a move to presumed consent may also increase living organ donation, through developing a culture of increased organ donations. Live Organ Donor Assistance, in the form of

230 At 15439 per Judy Turner.

231 Howard, above n 145, at 235.

232 (May 3 2006) 630 NZPD 2750.

233 See Part IVC of this paper. 
income assistance and childcare costs, is currently available to living donors who altruistically donate kidney or liver tissue for transplantation purposes. ${ }^{234}$ This assistance covers some loss of income and any extra childcare costs because of the transplantation operation. ${ }^{235}$ It is welfare assistance, rather than financial reward and should continue to be provided under the proposed presumed consent system.

\section{The role of Organ Donation New Zealand}

Organ Donation New Zealand (ODNZ) is the national service for deceased organ and tissue donation, managed through the Auckland District Health Board and funded by the Ministry of Health. ${ }^{236}$ ODNZ co-ordinates organ donation and provides information and ongoing support to families of donors. It also audits donation practices in New Zealand and works with health professionals in donor hospitals to ensure there are nationally consistent processes for deceased donation, as well as providing education for health professionals. ${ }^{237}$

Some of the services ODNZ currently provide include Link Teams, who act as liaisons for organ donation in ICU units in hospitals and donor co-ordinators who provide a 24-hour service for referrals from ICUs for organ donation and information and support for donor families throughout the process. ODNZ also organises 'Thanksgiving Services' for individual donor families, and study days and professional education for ICU staff. ${ }^{238}$ In terms of public awareness, ODNZ held a Thank You Day in 2012 to coincide with World Kidney Day, to thank donors and donor families. In 2012 ODNZ continued developing an education programme about transplantation to be used in schools throughout the country. A programme for $14-15$ year old students is due to be released in $2013 .{ }^{239}$ General education resources can be found on the ODNZ website. ${ }^{240}$

ODNZ's programmes are examples of non-legislative initiatives being undertaken with the aim of improving organ donation rates. Despite ODNZ's focus on improvement of organ and tissue donation, and the culture of altruism created by the

\footnotetext{
234 Work and Income "Live Organ Donor Assistance" <www.workandincome.govt.nz>.

235 Work and Income "Live Organ Donor Assistance" <www.workandincome.govt.nz>.

236 Organ Donation New Zealand Annual Report 2012 (2012) at 2.

237 At 3.

238 At $3-4$

239 At 5 .

240 Organ Donation New Zealand "Education Units" <www.donor.co.nz>.
} 
Thanksgiving Services, New Zealand has not shown an increased rate of organ donation. New Zealand should not rely only upon non-legislative initiatives to increase donation rates, but actively implement legal measures aimed at improving donation rates.

\section{$D \quad$ United Kingdom Experience}

The United Kingdom experience is similar to that of New Zealand. In January 2004 the House of Commons debated the Organ Donation (Presumed Consent and Safeguards) Bill, which proposed a presumed consent system. ${ }^{241}$ The British Medical Association supported this move, having voted in favour of presumed consent at its annual meeting in 1999. ${ }^{242}$ Dr Michael Wilks, the Chairman of the British Medical Association's Ethics Committee argued in favour of presumed consent, noting, "we must increase the number of donors available and we believe that a system of presumed consent with safeguards, will do this." 243 On the other hand, then Minister of State for Health Rosie Winterton ruled out the bill because of perceived ethical problems of the presumed consent system and said "full consent must be obtained to use human organs and tissue." 244

The UKHTA was passed in place of the Organ Donation (Presumed Consent and Safeguards) Bill. During the debates for what became the Human Tissue Act, presumed consent was again suggested as "one way to bridge the gap between what people say they want to do and what they actually do would be to adopt a system of presumed consent". ${ }^{245}$ Winterton noted that presumed consent had been given "serious consideration" but that the principle of the Act was informed consent. ${ }^{246}$ However, UKHTA does implement a national register that takes precedence over the objections of family members. ${ }^{247}$ The UKHTA also prohibits commercial dealings in human material. ${ }^{248}$ The United Kingdom offers an interesting case study; although presumed consent was rejected, it was hotly debated, and the resulting UKHTA

241 Organ Donation (Presumed Consent and Safeguards) Bill 2004.

242 (15 January 2004) 416 GBPD HC 1033; Charles A Erin and John Harris "An ethical market in human organs" (2003) 29 J Med Ethics 137 at 137.

243 At 137.

244 At 137.

245 (15 January 2004) 416 GBPD HC 1010.

246 At 1010.

247 Human Tissue Act 2004, s 3.

248 Section 32. See Appendix 3 for provisions. 
provides stronger protections of informed consent and sanctions on sale of organs that the New Zealand HTA. Given the similarities between the United Kingdom system and the New Zealand system, New Zealand should model the strong aspects of the UKHTA, whilst spearheading reform through hard presumed consent. Interestingly, in September 2013, the National Assembly for Wales passed the Human Transplantation (Wales) Act 2013, which introduces soft presumed consent in Wales. ${ }^{249}$ The Act means that organ procurement in Wales is now different from that of the rest of the United Kingdom. ${ }^{250}$ The new system under the Act will not come into effect until 2015, to allow time for a major public information campaign. ${ }^{251}$ This paper suggests the same public education approach for the proposed New Zealand presumed consent system.

\section{Conclusion}

The worldwide shortage of organs has led to the growth of a black market in organ trade and an increase in organ trafficking. The transboundary nature of organ trafficking and transplant tourism means that it is an issue that requires both domestic and international regulation. A cohesive, holistic approach to reducing organ trafficking encompasses destination country enforcement, international conventions, extraterritorial criminalisation (particularly for importing states) and domestic selfsufficiency in organ procurement. This paper has focused on domestic selfsufficiency. Destination country enforcement and extraterritorial criminalisation rely on states to prioritise, and enforce laws against organ trafficking; this has been shown to be lacking. There has not yet been a decisive response from the international community. The international conventions concerning organ trafficking are vague and rely inter-state co-operation. Therefore, increasing the supply of organs locally is the most realistic option for reducing organ trafficking. States have an individual responsibility to amend their domestic legislation to address the organ shortage, rather than relying on international law, which cannot in itself provide a comprehensive solution to the organ trafficking problem.

This paper has focused on New Zealand, as a window into how a state in the international community may increase local supply. Hard presumed consent is the

249 Human Transplantation (Wales) Act 2013.

250 Allowed under the Government of Wales Act 2006.

251 BBC "Q\&A: Organ donation planned changes in Wales" (1 July 2013) <www.bbc.co.uk/news>. 
system of organ procurement that has proven to effectively increase organ donation rates. States, including New Zealand, should adopt presumed consent systems. Presumed consent weaves together the threads of individual autonomy and informed consent, fundamental principles of medical law, while remaining rooted in altruism.

Implementing a system of presumed consent represents a starting point for addressing the international organ shortage, a root cause of organ trafficking. Any change in organ donation in system in New Zealand will require careful consideration of various cultural and societal perspectives, notably Māori perspectives. A move to presumed consent must be accompanied by effective infrastructure and public education. The discussion of proposed presumed consent in New Zealand provides a framework for other states who should also implement presumed consent, to harmonise global organ procurement. To do so, states must not only implement a legal framework for organ donation, but also focus on public education and community building. Only then may the worldwide shortage of organs be effectively addressed, and in turn, international organ trafficking. 


\section{Appendix 1: World Health Organisation Definitions}

All definitions are taken from the World Health Organisation "Global Glossary of Terms and Definitions on Donation and Transplantation" (Geneva, November 2009).

\section{Brain Death}

Irreversible cessation of cerebral and brain stem function; characterized by absence of electrical activity in the brain, blood flow to the brain, and brain function as determined by clinical assessment of responses. A brain dead person is dead, although his or her cardiopulmonary functioning may be artificially maintained for some time.

\section{Cardiac Death}

Death resulting from the irreversible cessation of circulatory and respiratory function; an individual who is declared dead by circulatory and respiratory criteria may donate tissues and organs for transplantation.

\section{Consent to donation}

Legally valid permission for removal of human cells, tissues and organs for transplantation.

\section{Donation}

Donating human cells, tissues or organs intended for human applications.

\section{Donor}

A human being, living or deceased, who is a source of cells, tissues or organs for the purpose of transplantation.

\section{Explicit consent}

Legally valid permission for removal of human cells, tissues and organs for transplantation, Otherwise known

as 'opting in'.

\section{Exported / Export}

Human bodies, body parts, cells, tissues or organs for human application, legally procured inside of the national boundary and transported to another country where it 
is to be further processed or used. Export must be according local (exporting country) laws, international laws and conventions and receiving country laws.

\section{Imported / Import}

Human bodies, body parts, cells, tissues and organs for human application, legally procured outside of the national boundary to which it has been transported for use. Importation must be according local (receiving country) laws, international laws and conventions and supplying country laws.

Informed Consent A person's voluntary agreement, based upon adequate knowledge and understanding of relevant information,

to participate in research or to undergo a diagnostic, therapeutic, or preventive procedure.

\section{Organ}

Differentiated and vital part of the human body, formed by different tissues, that maintains its structure, vascularisation and capacity to develop physiological functions with an important level of autonomy.

Presumed consent Legally valid presumption of permission for removal of cells, tissues and organs for transplantation, in the absence of individual pre-stated refusal of permission. Otherwise known as 'opting out'. 
Appendix 2: Statistics from the ANZDATA Registry 2012 Annual Report.

These statistics offer some insight into the demographics of organ donors in New Zealand

Table 2:

Cause of Donor Death

by Year

\begin{tabular}{l|l|l|l|l|l|} 
& 2008 & 2009 & 2010 & 2011 & 2012 \\
\hline CVA & 22 & 21 & 22 & 19 & 14 \\
\hline TRAUMA (ROAD) & 2 & 9 & 9 & 6 & 4 \\
\hline TRAUMA (OTHER) & 3 & 4 & 4 & 4 & 8 \\
\hline HYPOXIA-ANOXIA & 4 & 8 & 2 & 8 & 7 \\
\hline OTHER & 0 & 1 & 4 & 1 & 5 \\
\hline TOTAL & 41 & 43 & 41 & 38 & 38 \\
\hline
\end{tabular}

Table 4:

Ethnicity of

Deceased Donors

by Year

\begin{tabular}{l|l|l|l|l|l} 
& 2008 & 2009 & 2010 & 2011 & 2012 \\
\hline EUROPEAN & 27 & 35 & 32 & 30 & 28 \\
\hline MAORI & 3 & 5 & 5 & 3 & 6 \\
\hline PACIFIC PEOPLE & 1 & 0 & 1 & 4 & 1 \\
\hline OTHER & 0 & 3 & 3 & 1 & 3 \\
\hline TOTAL & 31 & 43 & 41 & 38 & 38 \\
\hline
\end{tabular}

Table 5:

Organs and Tissues

Retrieved from

Deceased Donors

and Transplanted

\begin{tabular}{|c|c|c|c|c|c|}
\hline & 2008 & 2009 & 2010 & 2011 & 2012 \\
\hline KIDNEYS* & 53 & $56(4)$ & $56[8]$ & $65[8]$ & 54 \\
\hline HEARTS & 10 & 11 & 11 & 12 & 12 \\
\hline LUNGS. & 14 & 16 & 16 & 13 & 12 \\
\hline LIVER $*$ & 23 & 33 & 33 & 30 & 29 \\
\hline PANCREAS & 4 & 2 & 2 & 3 & 2 \\
\hline CORNEAS* & 15 & 13 & 13 & 16 & 14 \\
\hline HEART VALVES $*$ & 8 & 8 & 8 & 11 & 9 \\
\hline SKIN $*$ & 3 & 4 & 4 & 3 & 2 \\
\hline
\end{tabular}


Appendix 3: Statutes

Human Tissue Act 2008

\section{Section 56 Trading in human tissue generally prohibited}

(1) No person may, except under an exemption under section 60, require or accept, or offer or provide, financial or other consideration for human tissue.

(2) A person commits an offence, and is liable on summary con- viction to imprisonment for a term not exceeding 1 year or a fine not exceeding $\$ 50,000$, if -

(a) the person intentionally or knowingly does an act; and

(b) that act contravenes subsection (1)

United Kingdom Human Tissue Act 2004

Trafficking

Section 32 Prohibition of commercial dealings in human material for transplantation

(1) A person commits an offence if he-

(a) gives or recieves a reward for the supply of, or for an offer to supply, any controlled material;

(b) seeks to find a person willing to supply any controlled material for reward;

(c) offers to supply any controlled material for reward;

(d) initiates or negotiates any arrangement involving the giving of a reward for the supply of, or for an offer to supply, any controlled material;

(e) takes part in the management or control of a body of persons corporate or unincorporate whose activities consist of or include the initiation or negotiation of such arrangements.

Crimes Act 1961

Section 98D Trafficking in people by means of coercion or deception 
(1) Every one is liable to the penalty stated in subsection (2) who-

(a) arranges the entry of a person into New Zealand or any other State by 1 or more acts of coercion against the person, 1 or more acts of deception of the person, or both; or

(b) arranges, organises, or procures the reception, concealment, or harbouring in New Zealand or any other State of a person, knowing that the person's entry into New Zealand or that State was arranged by 1 or more acts of coercion against the person, 1 or more acts of deception of the person, or both.

(2) The penalty is imprisonment for a term not exceeding 20 years, a fine not exceeding $\$ 500,000$, or both.

(3) Proceedings may be brought under this section even if the person coerced or deceived-

(a) did not in fact enter the State concerned; or (as the case may be)

(b) was not in fact received, concealed, or harboured in the State concerned.

(4) Proceedings may be brought under this section even if parts of the process by which the person coerced or deceived was brought or came to or towards the State concerned were accomplished without an act of coercion or deception.

\section{Section 98E Aggravating factors}

(1) When determining the sentence to be imposed on, or other way of dealing with, a person convicted of an offence against section $98 \mathrm{C}$ or section $98 \mathrm{D}$, a court must take into account-

(a) whether bodily harm or death (whether to or of a person in respect of whom the offence was committed or some other person) occurred during the commission of the offence: 
(b) whether the offence was committed for the benefit of, at the direction of, or in association with, an organised criminal group (within the meaning of section $98 \mathrm{~A}(2))$ :

(c) whether a person in respect of whom the offence was committed was subjected to inhuman or degrading treatment as a result of the commission of the offence:

(d) if during the proceedings concerned the person was convicted of the same offence in respect of 2 or more people, the number of people in respect of whom the offence was committed.

(2) When determining the sentence to be imposed on, or other way of dealing with, a person convicted of an offence against section $98 \mathrm{D}$, a court must also take into account-

(a) whether a person in respect of whom the offence was committed was subjected to exploitation (for example, sexual exploitation, a requirement to undertake forced labour, or the removal of organs) as a result of the commission of the offence:

(b) the age of the person in respect of whom the offence was committed and, in particular, whether the person was under the age of 18 years:

(c) whether the person convicted committed the offence, or took actions that were part of it, for a material benefit.

(3) The examples in paragraph (a) of subsection (2) do not limit the generality of that paragraph.

(4) This section does not limit the matters that a court may take into account when determining the sentence to be imposed on, or other way of dealing with, a person convicted of an offence against section 98C or section 98D. 


\section{Section 98F Attorney-General's consent to prosecutions required}

(1) Proceedings for an offence against section 98C or section 98D cannot be brought in a New Zealand court without the Attorney-General's consent.

(2) A person alleged to have committed an offence against section 98C or section 98D may be arrested, or a warrant for the person's arrest may be issued and executed, and the person be remanded in custody or on bail, even though the Attorney-General's consent to the bringing of proceedings against the person has not been obtained. 


\section{Bibliography}

\section{A Legislation}

$1 \quad$ New Zealand

Code of Health and Disability Services Consumers' Rights 1996.

Crimes Act 1961.

Electoral Act 1993.

Health and Disability Commissioner Act 1994.

Human Tissue Act 2008.

Human Tissue Bill 2006 (82 - 2) (select committee report).

Human Tissue (Organ Donation) Amendment Bill (33 - 1) (select committee report).

2 United Kingdom

Government of Wales Act 2006.

Human Tissue Act 2004.

Human Transplantation (Wales) Act 2013.

Organ Donation (Presumed Consent and Safeguards) Bill 2004.

\section{B Treaties}

Council of Europe Convention on Action Against Trafficking in Human Beings CETS 197 (opened for signature 16 May 2005, entered into force 1 February 2008).

Council of Europe Convention for the Protection of Human Rights and Dignity of the Human Being with regard to the Application of Biology and Medicine: Convention on Human Rights and Biomedicine ETS 164 (opened for signature 4 April 1997, entered into force 1 December 1999).

Council of Europe Additional Protocol to the Convention on Human Rights and Biomedicine concerning Transplantation of Organs and Tissues of Human Origin 
ETS 186 (opened for signature 25 January 2005, entered into force 1 December 2009).

International Covenant on Civil and Political Rights 999 UNTS 171 (opened for signature 16 December 1966, entered into force 23 March 1976).

International Covenant on Economic, Social and Cultural Rights 993 UNTS 3 (opened for signature 16 December 1966, entered into force 3 January 1976).

Protocol to Prevent, Suppress and Punish Trafficking in Persons, Especially Women and Children, supplementing the United Nations Convention against Transnational Organised Crime 2237 UNTS 319 (opened for signature 15 November 2000, entered into force 25 December 2003).

Rome Statute of the International Criminal Court 2187 UNTS 38544 (opened for signature 17 July 1998, entered into force 1 July 2002).

Universal Declaration of Human Rights (ratified 10 December 1948).

United Nations Convention against Transnational Organised Crime (opened for signature 12 December 2000, entered into force 29 September 2003).

\section{International Materials}

$1 \quad$ Preparatory Documents

United Nations Diplomatic Conference of Plenipotentiaries on the Establishment of an International Criminal Court - Official Records A/CONF 183.13, II (1998).

United Nations Office on Drugs and Crime Travaux Préparatoires of the negotiations of the United Nations Convention against Transnational Organised Crimes and the Protocols thereto (United Nations, 2006).

\section{United Nations Materials}

World Health Organisation Development of guiding principles for human organ transplants WHA 40.13 (1987).

World Health Organisation Human organ and tissue transplantation WHA57.18 (2004). 
World Health Organisation "Global Glossary of Terms and Definitions on Donation and Transplantation" (Geneva, November 2009).

World Health Organisation Human organ and tissue transplantation WHA63.22 (2010).

World Health Organisation "WHO Guiding Principles on Human Cell, Tissue and Organ Transplantation" (2010).

\section{Other}

The Transplantation Society and International Society of Nephrology "Declaration of Istanbul on Organ Trafficking and Transplant Tourism" (declaration made at the International Summit on Transplant Tourism and Organ Trafficking, April 2008).

World Medical Association "Statement on Human Organ, Tissue Donation and Transplantation" (52nd General Assembly, Edinburgh, October 2000).

\section{Books and Chapters in Books}

T Randolph Beard, David L Kaserman and Rigmar Osterkamp The Global Organ Shortage: Economic Causes, Human Consequences, Policy Responses (Stanford University Press, Redwood City, 2013).

Alastair Campbell, Grant Gillett and Gareth Jones Medical Ethics (Oxford University Press, Auckland, 2005).

David Collins Medical Law in New Zealand (Brooker \& Friend, Wellington, 1992).

Michele Goodwin Black Markets: The Supply and Demand of Body Parts (Cambridge University Press, New York, 2006).

Joanna Manning (ed) The Cartwright Paper: Essays on the Cervical Cancer Inquiry 1987 - 88 (Bridget Williams Books, Wellington, 2009).

Ronald Munson Raising the Dead: Organ Transplants, Ethics and Society (Oxford University Press, Oxford, 2002).

David J Rothman and Sheila M Rothman Trust is Not Enough: Bringing Human Rights to Medicine (The New York Review of Books, New York, 2006). 
Michael Sandel What Money Can't Buy: The Moral Limits of Markets (Penguin Group, London, 2013).

Richard M Titmuss The Gift Relationship: From Human Blood to Social Policy (George Allen \& Unwin, London, 1970).

\section{E Journal Articles}

Alberto Abadie and Sebastien Gay "The impact of presumed consent legislation on cadaveric organ donation: a cross-country study" (2006) 25 Journal of Health Economics 599.

Helen Allrich, Elizabeth Dougall and David Heneghan "Donate Life California: A Campaign Launch Case Study" (2007) 1 Cases in Public Health Communication \& Marketing 1.

Richard Michael Boyce "Organ Transplantation Crisis: Should the Deficit Be Eliminated Through Inter Vivos Sales?" (1984) 17 Akron L Rev 283.

J Randall Boyer "Gifts of the Heart...and Other Tissues: Legalizing the Sale of Human Organs and Tissues" [2012] BYU L Rev 313.

D A Budiani-Saberi and F L Delmonico "Organ Trafficking and Transplant Tourism: A Commentary on the Global Realities" (2008) 8 American Journal of Transplantation 925 .

James F Childress "Ethical Criteria for Procuring and Distributing Organs for Transplantation" (1989) 14 J Health Polit Policy Law 87.

P Chouhan and H Draper "Modified mandated choice for organ procurement" (2003) 29 J Med Ethics 157.

I Glenn Cohen "Transplant Tourism: the Ethics and Regulation of International Markets for Organs" (2013) 41 J L Med \& Ethics 269.

Lloyd R Cohen "Increasing the Supply of Transplant Organs: The Virtues of a Futures Market" (1990) 58 Geo Wash L Rev 1. 
Remco Coppen, Roland D Friele, Jouke van der Zee and Sjef K Gevers "The potential of legislation on organ donation to increase the supply of donor organs" (2010) 98 Health Policy 164.

Claudio Csillag "Brazil abolishes presumed consent in organ donation" (1998) 352 The Lancet 1367.

Eduardo Dantas "When Consent is Not Enough: The Construction and Development of the Modern Concept of Autonomy" (2011) 30 Med Law 461.

F L Delmonico " Ethical Incentives - Not Payment - For Organ Donation" (2002) 346 N Engl J Med 2002.

F L Delmonico and Nancy Scheper-Hughes "Why We Should Not Pay For Human Organs" (2003) 38 Zygon 689.

F L Delmonico "The development of the Declaration of Istanbul on Organ Trafficking and Transplant Tourism" (2008) 23 Nephrol Dial Transplant 3381.

F L Delmonico "The implications of Istanbul Declaration on organ trafficking and transplant tourism" (2009) 14 Current Opinion in Organ Transplantation 116.

F L Delmonico, Beatriz Dominguez-Gil, Rafael Matesanz and Luc Noel "A call for government accountability to achieve national self-sufficiency in organ donation and transplantation" (2011) 378 The Lancet 1414.

Charles A Erin and John Harris "An ethical market in human organs" (2003) 29 J Med Ethics 137.

Amitai Etzioni "Organ Donation: A Communitarian Approach" (2003) 13 Kennedy Institute of Ethics J 1.

John Fabre "Presumed consent is unnecessary" (2010) 341 BMJ 922.

M R First "Cadaveric Organ Procurement - An Overview of Two Aspects: Donor Hospital Networks and Minority Donation" (1997) 29 Transplantation Proceedings 70.

Leslie P Francis and John G Francis "Stateless Crimes, Legitimacy, and International Criminal Law: The Case of Organ Trafficking" (2010) 4 Crim L and Philos 283. 
Gilbert Geis and Gregory C Brown "The Transnational Traffic in Human Body Parts" (2008) 24 Journal of Contemporary Criminal Justice 212.

Sjef Gevers, Anke Janssen and Roland Friele "Consent Systems for Post Mortem Organ Donation in Europe" (2004) 11 EJHL 175.

Michael B Gill "Presumed Consent, Autonomy, and Organ Donation" (2004) 29 Journal of Medicine and Philosophy 37.

Michael B Gill and Robert M Sade "Paying for Kidneys: The Case against Prohibition" (2002) 12 Kennedy Institute Ethics J 17.

Sheri R Glaser "Formula to Stop the Illegal Organ Trade: Presumed Consent Laws and Mandatory Reporting Requirements for Doctors" (2005) 12 Hum Rts Brief 20.

Henry Hansmann "The Economics and Ethics of Markets for Human Organs" (1989) 14 J Health Polit Policy Law 57

Kieran Healy "Do Presumed Consent Laws Raise Organ Procurement Rates?" (2006) 55 DePaul L Rev 1017.

Jennifer J Howard "Fatal Flaws: New Zealand's Human Tissue Act Fails to Provide an Avenue for Individuals to Give Legally Binding Informed Consent" (2013) 22 Pac Rim L \& Poly J 209.

Richard Howard "How Can We Increase the Number of Organ and Tissue Donors?" (1999) 188 J Am Coll Surg 317.

Michael P Jaycox "Coercion, Autonomy, and the Preferential Option for the Poor in the Ethics of Organ Transplantation" (2012) 12 Developing World Bioethics 135.

Troy R Jensen "Organ Procurement: Various Legal Systems and their Effectiveness" (2000) 22 Hous J Intl L 555.

Eric J Johnson and Daniel Goldstein "Do Defaults Save Lives?" (2003) 302 Science 1338.

R R Kishore "Human organs, scarcities, and sale: morality revisited" (2005) 31 J Med Ethics 362. 
Greg Lewis and Neil Pickering "Māori Spiritual Beliefs and Attitudes Towards Organ Donation" (2003) 4 NZ Bioeth J 31.

Andrew C MacDonald "Organ Donation: The Time Has Come to Refocus the Ethical Spotlight" (1997) 8 Stan L \& Pol'y Rev 177.

Arthur J Matas "The Case for Living Kidney Sales: Rationale, Objections and Concerns" (2004) 4 American Journal of Transplantation 2007.

Jean V McHale "Organ Transplantation, the Criminal Law and the Health Tourist: A Case for Extraterritorial Jurisdiction?" (2013) 22 Cambridge Quarterly of Healthcare Ethics 64.

Eytan Mor and Hagai Boas "Organ Trafficking: Scope and Ethical Dilemma" (2005) 5 Current Diabetes Reports 294.

Maria N Morelli "Organ Trafficking: Legislative Proposals to Protect Minors" (1995) 10 AMU J Intl L \& Poly 917.

Elias Mossialos, Joan Costa-Font and Caroline Rudisill "Does organ donation legislation affect individuals' willingness to donate their own or their relative's organs? Evidence from European Union survey data" (2008) 8 BMC 48.

Ranee Panjabi "The Sum of a Human's Parts: Global Organ Trafficking in the Twenty-First Century" (2011) 28 Pace Envtl L Rev 1.

C Petrini "Ethical Issues With Informed Consent From Potential Living Kidney Donors" (2010) 42 Transplantation Proceedings 1040.

F T Rapaport "Current Status and Future Prospects for Organ Procurement and Retrieval" (1999) 31 Transplantation Proceedings 1763.

A Rithalia, C McDaid, S Suekarran, G Norman, L Myers and A Sowden "A systematic review of presumed consent systems for deceased organ donation" (2009) 13 Health Technology Assessment 1.

Justin Roake "Gifts of life in short supply" (2002) 115 NZMJ 1. 
Noor Robson, Azad Razack and Norman Dublin "Organ Transplants: Ethical, Social and Religious Issues in a Multicultural Society" (2010) 22 Asia Pac J Public Health 271.

Nancy Scheper-Hughes "The Global Traffic in Human Organs" (2000) 41 Current Anthropology 191.

Nancy Scheper-Hughes "Keeping an eye on the global traffic in human organs" (2003) 361 The Lancet 1645.

Rhonda Shaw "Thanking and reciprocating under the New Zealand organ donation system" (2012) 16 Health 298.

Yosuke Shimazono "The state of the international organ trade: a provisional picture based on integration of available information" (2007) 85 Bulletin of the World Health Organisation 955.

Aaron Spital "Conscription of Cadaveric Organs for Transplantation: Neglected Again" (2003) 13 Kennedy Institute of Ethics J 169.

Sarah Elizabeth Statz "Finding the Winning Combination: How Blending Organ Procurement Systems Used Internationally Can Reduce the Organ Shortage" (2006) 39 Vand J Transnatl L 1677.

Erica Teagarden "Human Trafficking: Legal Issues in Presumed Consent Laws" (2005) 30 NCJ Intl \& Com Reg 685.

Robert D Truog "Consent for Organ Donation - Balancing Conflicting Ethical Obligations" (2008) 12 N Engl J Med 358.

Robert M Veatch "Why Liberals Should Accept Financial Incentives for Organ Procurement" (2003) 13 Kennedy Institute of Ethics J 19.

Joseph L Verheijde, Mohamed Y Rady, Joan L McGregor and Catherine FriederichMurray "Enforcement of presumed consent policy and willingness to donate organs as identified in the European Union survey: the role of legislation in reinforcing ideology in pluralistic societies" (2009) 90 Health Policy 26. 
A Vincent and L Logan "Consent for organ donation" (2012) 108 British Journal of Anaesthesia 80 .

Rory Watson "European Parliament Tries to Stamp Out Trafficking in Human Organs" (2003) 327 British Medical Journal 1009.

Robert Webb and Rhonda Shaw "Whanau, Whakapapa and Identity in Experiences of Organ Donation and Transplantation" (2011) 8 SITES: New Series 40.

Christian Williams "Combatting the Problems of Human Rights Abuses and Inadequate Organ Supply Through Presumed Donative Consent" (1994) 26 Case W Res J Int'l L 315.

Sunny Woan "Buy Me a Pound of Flesh: China's Sale of Death Row Organs on the Black Market and What Americans Can Learn From It" (2007) 47 Santa Clara L Rev 413.

Sheldon Zink, Rachel Zeehandelaar and Stacey Wertlieb "Presumed vs Expressed Consent in the US and Internationally" (2005) 7 Virtual Mentor 1.

T L Zutlevics "Markets and the Needy: Organ Sales or Aid?" (2001) 18 J Applied Philosophy 297.

\section{F Parliamentary and Government Materials}

$1 \quad$ New Zealand Hansard

(3 May 2006) 630 NZPD 2748.

(23 October 2007) 643 NZPD 12607.

(6 November 2007) 643 NZPD 12838.

(7 November 2007) 643 NZPD 12896.

(13 November 2007) 643 NZPD 13051.

(14 November 2006) 635 NZPD 6467.

(11 March 2008) 645 NZPD 14799.

(19 March 2008) 646 NZPD 15104. 
(8 April 2008) 646 NZPD 15428.

2 United Kingdom Hansard

(15 January 2004) 416 GBPD HC 984.

3 Other

Capital and Coast District Health Board "Tikanga Māori: A Guide for Health Care Workers" (2009).

\section{G Reports}

ANZDATA Registry 2010 Annual Report (2010).

ANZDATA Registry 2011 Annual Report (2011).

ANZDATA Registry 2012 Annual Report (2012).

Mauri Ora Associates Māori Pacific Attitudes Towards Transplantation: Professional Perspectives (Ministry of Health, October 2009).

Organ Donation New Zealand Annual Report 2010 (2010).

Organ Donation New Zealand Annual Report 2011 (2011).

Organ Donation New Zealand Annual Report 2012 (2012).

Te Puni Kōkiri Hauora o te Tinana me ōna Tikanga Service Providers (1999).

Te Puni Kōkiri Hauora o te Tinana me ōna Tikanga Māori and their Whanau (1999).

\section{H Dissertations and Research Papers}

Judith Sander "Organ Donation in New Zealand - A Reform Proposal for the Human Tissue Act 2008" (LLM Research Essay, Victoria University of Wellington, 2011).

Cordelia Mary Thomas "A Framework for the Collection, Retention and Use of Human Body Parts" (PhD Law Thesis, Victoria University of Wellington, 2006).

\section{Internet Resources}


BBC "Q\&A: Organ donation planned changes in Wales" (1 July 2013) $<$ www.bbc.co.uk/news $>$.

Cynulliad Cenedlaethol Cymru - National Assembly for Wales "Human Transplantation (Wales) Act 2013" <www.senedd.assemblywales.org>.

LifeSharers New Zealand "How LifeSharers Works" < lifesharers.org.nz>.

Matthew Backhouse "NZ organ donation rate among the world's lowest" The New Zealand Herald (online ed, New Zealand, 26 January 2013).

Organ Donation New Zealand "Education Units" <www.donor.co.nz>.

Organ Donation New Zealand "International Donor Rates" <www.donor.co.nz>.

Organ Donation New Zealand "Resources" <www.donor.co.nz>.

Organ Donation New Zealand "Statistics" <www.donor.co.nz>.

Organ Donation New Zealand "Waitlist" <www.donor.co.nz>.

United Nations Treaty Collection "Status of Ratification" < treaties.un.org>.

Work and Income "Live Organ Donor Assistance" <www.workandincome.govt.nz>.

\section{$J \quad$ Other}

The Māori Party "Tariana Turia: Human Tissue Bill" (press release, 9 April 2008). 